\title{
Metallogeny of the Great Basin: Crustal Evolution, Fluid Flow, and Ore Deposits
}

Open-File Report 2006-1280 


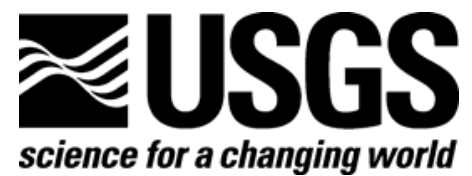

\section{Metallogeny of the Great Basin: Crustal Evolution, Fluid Flow, and Ore Deposits}

By Albert H. Hofstra' and Alan R. Wallace ${ }^{2}$

1-USGS, MS-973, Box 25046, Denver, C0 80225, <ahofstra@usgs.gov>

2-USGS, Mackay School of Earth Sciences, MS-176, Reno, NV, 89557, <alan@usgs.gov>

Open-File Report 2006-1280 


\section{U.S. Department of the Interior DIRK KEMPTHORNE, Secretary}

\section{U.S. Geological Survey \\ P. Patrick Leahy, Acting Director}

U.S. Geological Survey, Reston, Virginia 2006

For product and ordering information:

World Wide Web: http://www.usgs.gov/pubprod

Telephone: 1-888-ASK-USGS

For more information on the USGS - the Federal source for science about the Earth, its natural and living resources, natural hazards, and the environment:

World Wide Web: http://www.usgs.gov

Telephone: 1-888-ASK-USGS

Any use of trade, product, or firm names is for descriptive purposes only and does not imply endorsement by the U.S. Government.

Although this report is in the public domain, permission must be secured from the individual copyright owners to reproduce any copyrighted material contained within this report.

Suggested citation:

Hofstra, A.H. and Wallace, A.R., 2006, Metallogeny of the Great Basin: Crustal Evolution, Fluid Flow, and Ore Deposits: U.S. Geological Survey Open-File Report 2006-1280, 36 p. 


\section{Contents}

Abstract

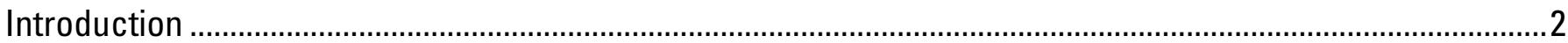

Relation to previous and current USGS projects in the region .....................................................................

Synergies with others

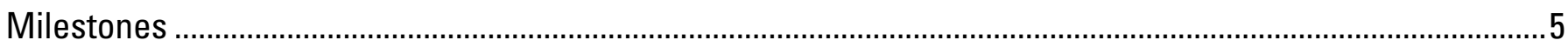

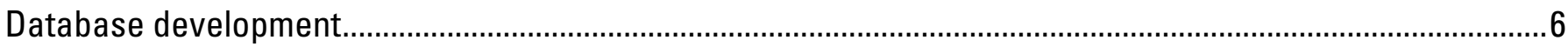

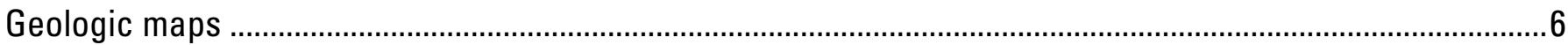

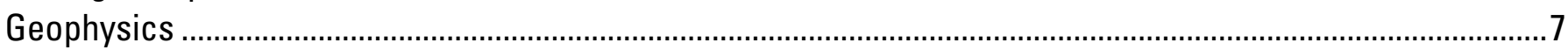

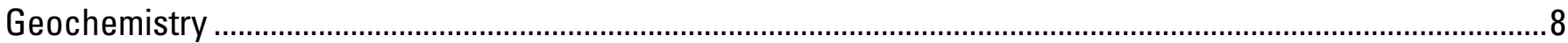

Neoproterozoic to Devonian passive margin .............................................................................................

Late Paleozoic and Mesozoic contraction......................................................................................................

Mesozoic and Cenozoic arc magmatism and pluton-related ore deposits ...................................................10

Paleogene basins, magmatism, faulting, and ore deposits .......................................................................... 10

Neogene basins, magmatism, faulting, and epithermal ore deposits............................................................11

Regional and district scale geologic and hydrologic models ..................................................................13

Metallogeny of the Great Basin Bibliography: 2002-2006 publications by USGS personnel and

collaborators

\section{Figures}

1. Significant metal deposits in the Great Basin (black outline) from Hofstra (2005b). Dot size is proportional to the amount of metal in the deposits ( $\mathrm{t}=$ tons, Kt= kilotons)

2. Color shaded relief map showing the location of gold deposits (see explanation, $B M=$ base metal), state boundaries (dark lines), and Metallogeny of the Great Basin (MGB) project study areas: Great Basin (yellow dashed line), Northern Nevada (orange box), and mining districts (Carlin trend, Beowawe/Mule Canyon-magenta boxes). The blue box outlines the previous Department of Energy/Water Resources Discipline Death Valley Region 3-D Hydrogeologic Study Area around the Nevada Test Site.

3. Example of a topical map/database product on geophysical terrains by Glen and others (2004a) that summarizes the attributes and inferred sources of magnetic and gravity anomalies across the Great Basin.

4. A revised 1:250,000 scale Nevada State Digital Geologic Map was produced by Crafford (2005; in press) to frame development of regional cross sections and 3-D models

5. Three-dimensional perspective view of some of the regional geologic cross sections in the northern

Nevada study area by Sweetkind and others $(2005 a, b)$

6. Example of a 3-D hydrogeologic model ( 0 al= Quaternary alluvium, Tv=Tertiary volcanic rocks, RMA=siliciclastic rocks of the Roberts Mountains Allochthon, Pz Ls=Paleozoic carbonate rocks) and grid used for flow modeling in the Beowawe geothermal area by Tilden and others (2005) .......34

7. Examples of 2-D hydrogeologic models for the Beowawe geothermal area and Eocene Carlin trend by Person and others (2005; AFT=apatite fission track)

8. Diagram showing the hierarchical nature of geologic data from Yager and Hofstra (2004) ........................36 


\section{Conversion Factors}

\section{Inch/Pound to SI}

\begin{tabular}{|c|c|c|}
\hline Multiply & By & To obtain \\
\hline \multicolumn{3}{|l|}{ Length } \\
\hline inch (in.) & 2.54 & centimeter $(\mathrm{cm})$ \\
\hline inch (in.) & 25.4 & millimeter (mm) \\
\hline foot $(\mathrm{ft})$ & 0.3048 & meter $(\mathrm{m})$ \\
\hline mile (mi) & 1.609 & kilometer (km) \\
\hline mile, nautical (nmi) & 1.852 & kilometer (km) \\
\hline yard (yd) & 0.9144 & meter $(\mathrm{m})$ \\
\hline \multicolumn{3}{|l|}{ Area } \\
\hline acre & 4,047 & square meter $\left(\mathrm{m}^{2}\right)$ \\
\hline acre & 0.4047 & hectare (ha) \\
\hline acre & 0.4047 & square hectometer $\left(\mathrm{hm}^{2}\right)$ \\
\hline acre & 0.004047 & square kilometer $\left(\mathrm{km}^{2}\right)$ \\
\hline square foot $\left(\mathrm{ft}^{2}\right)$ & 929.0 & square centimeter $\left(\mathrm{cm}^{2}\right)$ \\
\hline square foot $\left(\mathrm{ft}^{2}\right)$ & 0.09290 & square meter $\left(\mathrm{m}^{2}\right)$ \\
\hline square inch $\left(\right.$ in $\left.^{2}\right)$ & 6.452 & square centimeter $\left(\mathrm{cm}^{2}\right)$ \\
\hline $\begin{array}{l}\text { section ( } 640 \text { acres or } 1 \text { square } \\
\text { mile) }\end{array}$ & 259.0 & square hectometer $\left(\mathrm{hm}^{2}\right)$ \\
\hline square mile $\left(\mathrm{mi}^{2}\right)$ & 259.0 & hectare (ha) \\
\hline square mile $\left(\mathrm{mi}^{2}\right)$ & 2.590 & square kilometer $\left(\mathrm{km}^{2}\right)$ \\
\hline \multicolumn{3}{|l|}{ Volume } \\
\hline $\begin{array}{l}\text { barrel (bbl), (petroleum, } \\
1 \text { barrel=42 gal) }\end{array}$ & 0.1590 & cubic meter $\left(\mathrm{m}^{3}\right)$ \\
\hline ounce, fluid (fl. oz) & 0.02957 & liter (L) \\
\hline pint (pt) & 0.4732 & liter (L) \\
\hline quart (qt) & 0.9464 & liter (L) \\
\hline gallon (gal) & 3.785 & liter $(\mathrm{L})$ \\
\hline gallon (gal) & 0.003785 & cubic meter $\left(\mathrm{m}^{3}\right)$ \\
\hline gallon (gal) & 3.785 & cubic decimeter $\left(\mathrm{dm}^{3}\right)$ \\
\hline million gallons (Mgal) & 3,785 & cubic meter $\left(\mathrm{m}^{3}\right)$ \\
\hline cubic inch $\left(\right.$ in $\left.^{3}\right)$ & 16.39 & cubic centimeter $\left(\mathrm{cm}^{3}\right)$ \\
\hline cubic inch $\left(\right.$ in $\left.^{3}\right)$ & 0.01639 & cubic decimeter $\left(\mathrm{dm}^{3}\right)$ \\
\hline cubic inch $\left(\right.$ in $\left.^{3}\right)$ & 0.01639 & liter (L) \\
\hline cubic foot $\left(\mathrm{ft}^{3}\right)$ & 28.32 & cubic decimeter $\left(\mathrm{dm}^{3}\right)$ \\
\hline cubic foot $\left(\mathrm{ft}^{3}\right)$ & 0.02832 & cubic meter $\left(\mathrm{m}^{3}\right)$ \\
\hline cubic yard $\left(\mathrm{yd}^{3}\right)$ & 0.7646 & $\begin{array}{l}\text { cubic meter }\left(\mathrm{m}^{3}\right) \\
\text { iv }\end{array}$ \\
\hline
\end{tabular}




\begin{tabular}{|c|c|c|}
\hline cubic mile $\left(\mathrm{mi}^{3}\right)$ & 4.168 & cubic kilometer $\left(\mathrm{km}^{3}\right)$ \\
\hline acre-foot (acre-ft) & 1,233 & cubic meter $\left(\mathrm{m}^{3}\right)$ \\
\hline acre-foot (acre-ft) & 0.001233 & cubic hectometer $\left(\mathrm{hm}^{3}\right)$ \\
\hline \multicolumn{3}{|l|}{ Flow rate } \\
\hline acre-foot per day (acre-ft/d) & 0.01427 & cubic meter per second $\left(\mathrm{m}^{3} / \mathrm{s}\right)$ \\
\hline acre-foot per year (acre-ft/yr) & 1,233 & cubic meter per year $\left(\mathrm{m}^{3} / \mathrm{yr}\right)$ \\
\hline acre-foot per year (acre-ft/yr) & 0.001233 & $\begin{array}{l}\text { cubic hectometer per year } \\
\left(\mathrm{hm}^{3} / \mathrm{yr}\right)\end{array}$ \\
\hline foot per second (ft/s) & 0.3048 & meter per second $(\mathrm{m} / \mathrm{s})$ \\
\hline foot per minute (ft/min) & 0.3048 & meter per minute $(\mathrm{m} / \mathrm{min})$ \\
\hline foot per hour (ft/hr) & 0.3048 & meter per hour $(\mathrm{m} / \mathrm{hr})$ \\
\hline foot per day (ft/d) & 0.3048 & meter per day $(\mathrm{m} / \mathrm{d})$ \\
\hline foot per year (ft/yr) & 0.3048 & meter per year $(\mathrm{m} / \mathrm{yr})$ \\
\hline cubic foot per second $\left(\mathrm{ft}^{3} / \mathrm{s}\right)$ & 0.02832 & cubic meter per second $\left(\mathrm{m}^{3} / \mathrm{s}\right)$ \\
\hline $\begin{array}{l}\text { cubic foot per second per square } \\
\text { mile }\left[\left(\mathrm{ft}^{3} / \mathrm{s}\right) / \mathrm{mi}^{2}\right]\end{array}$ & 0.01093 & $\begin{array}{l}\text { cubic meter per second per } \\
\text { square kilometer }\left[\left(\mathrm{m}^{3} / \mathrm{s}\right) / \mathrm{km}^{2}\right]\end{array}$ \\
\hline cubic foot per day $\left(\mathrm{ft}^{3} / \mathrm{d}\right)$ & 0.02832 & cubic meter per day $\left(\mathrm{m}^{3} / \mathrm{d}\right)$ \\
\hline gallon per minute (gal/min) & 0.06309 & liter per second $(\mathrm{L} / \mathrm{s})$ \\
\hline gallon per day (gal/d) & 0.003785 & cubic meter per day $\left(\mathrm{m}^{3} / \mathrm{d}\right)$ \\
\hline $\begin{array}{l}\text { gallon per day per square mile } \\
{\left[(\mathrm{gal} / \mathrm{d}) / \mathrm{mi}^{2}\right]}\end{array}$ & 0.001461 & $\begin{array}{l}\text { cubic meter per day per square } \\
\text { kilometer }\left[\left(\mathrm{m}^{3} / \mathrm{d}\right) / \mathrm{km}^{2}\right]\end{array}$ \\
\hline $\begin{array}{l}\text { million gallons per day } \\
(\mathrm{Mgal} / \mathrm{d})\end{array}$ & 0.04381 & cubic meter per second $\left(\mathrm{m}^{3} / \mathrm{s}\right)$ \\
\hline $\begin{array}{l}\text { million gallons per day per } \\
\text { square mile }\left[(\mathrm{Mgal} / \mathrm{d}) / \mathrm{mi}^{2}\right]\end{array}$ & 1,461 & $\begin{array}{l}\text { cubic meter per day per square } \\
\text { kilometer }\left[\left(\mathrm{m}^{3} / \mathrm{d}\right) / \mathrm{km}^{2}\right]\end{array}$ \\
\hline inch per hour (in/h) & 0.0254 & meter per hour $(\mathrm{m} / \mathrm{h})$ \\
\hline inch per year (in/yr) & 25.4 & millimeter per year (mm/yr) \\
\hline mile per hour $(\mathrm{mi} / \mathrm{h})$ & 1.609 & kilometer per hour $(\mathrm{km} / \mathrm{h})$ \\
\hline \multicolumn{3}{|l|}{ Mass } \\
\hline ounce, avoirdupois (oz) & 28.35 & $\operatorname{gram}(\mathrm{g})$ \\
\hline pound, avoirdupois (lb) & 0.4536 & kilogram $(\mathrm{kg})$ \\
\hline ton, short $(2,000 \mathrm{lb})$ & 0.9072 & megagram $(\mathrm{Mg})$ \\
\hline ton, long $(2,240 \mathrm{lb})$ & 1.016 & megagram $(\mathrm{Mg})$ \\
\hline ton per day (ton/d) & 0.9072 & metric ton per day \\
\hline ton per day (ton/d) & 0.9072 & megagram per day $(\mathrm{Mg} / \mathrm{d})$ \\
\hline $\begin{array}{l}\text { ton per day per square mile } \\
{\left[(\text { ton } / \mathrm{d}) / \mathrm{mi}^{2}\right]}\end{array}$ & 0.3503 & $\begin{array}{l}\text { megagram per day per square } \\
\text { kilometer }\left[(\mathrm{Mg} / \mathrm{d}) / \mathrm{km}^{2}\right]\end{array}$ \\
\hline ton per year (ton/yr) & 0.9072 & megagram per year $(\mathrm{Mg} / \mathrm{yr})$ \\
\hline ton per year (ton/yr) & 0.9072 & metric ton per year \\
\hline
\end{tabular}




\begin{tabular}{|c|c|c|}
\hline atmosphere, standard (atm) & 101.3 & kilopascal (kPa) \\
\hline bar & 100 & kilopascal (kPa) \\
\hline inch of mercury at $60^{\circ} \mathrm{F}$ (in $\mathrm{Hg}$ ) & 3.377 & kilopascal (kPa) \\
\hline $\begin{array}{l}\text { pound-force per square inch } \\
\left(\mathrm{lbf} / \mathrm{in}^{2}\right)\end{array}$ & 6.895 & kilopascal (kPa) \\
\hline pound per square foot $\left(\mathrm{lb} / \mathrm{ft}^{2}\right)$ & 0.04788 & kilopascal $(\mathrm{kPa})$ \\
\hline pound per square inch $\left(\mathrm{lb} / \mathrm{in}^{2}\right)$ & 6.895 & kilopascal $(\mathrm{kPa})$ \\
\hline \multicolumn{3}{|l|}{ Density } \\
\hline pound per cubic foot $\left(\mathrm{lb} / \mathrm{ft}^{3}\right)$ & 16.02 & $\begin{array}{l}\text { kilogram per cubic meter } \\
\left(\mathrm{kg} / \mathrm{m}^{3}\right)\end{array}$ \\
\hline pound per cubic foot $\left(\mathrm{lb} / \mathrm{ft}^{3}\right)$ & 0.01602 & $\begin{array}{l}\text { gram per cubic centimeter } \\
\left(\mathrm{g} / \mathrm{cm}^{3}\right)\end{array}$ \\
\hline \multicolumn{3}{|l|}{ Energy } \\
\hline kilowatthour (kWh) & $3,600,000$ & joule $(\mathrm{J})$ \\
\hline \multicolumn{3}{|l|}{ Radioactivity } \\
\hline picocurie per liter (pCi/L) & 0.037 & becquerel per liter $(\mathrm{Bq} / \mathrm{L})$ \\
\hline \multicolumn{3}{|l|}{ Specific capacity } \\
\hline $\begin{array}{l}\text { gallon per minute per foot } \\
[(\mathrm{gal} / \mathrm{min}) / \mathrm{ft})]\end{array}$ & 0.2070 & $\begin{array}{l}\text { liter per second per meter } \\
{[(\mathrm{L} / \mathrm{s}) / \mathrm{m}]}\end{array}$ \\
\hline \multicolumn{3}{|l|}{ Hydraulic conductivity } \\
\hline foot per day (ft/d) & 0.3048 & meter per day $(\mathrm{m} / \mathrm{d})$ \\
\hline \multicolumn{3}{|l|}{ Hydraulic gradient } \\
\hline foot per mile $(\mathrm{ft} / \mathrm{mi})$ & 0.1894 & meter per kilometer $(\mathrm{m} / \mathrm{km})$ \\
\hline \multicolumn{3}{|l|}{ Transmissivity* } \\
\hline foot squared per day $\left(\mathrm{ft}^{2} / \mathrm{d}\right)$ & 0.09290 & meter squared per day $\left(\mathrm{m}^{2} / \mathrm{d}\right)$ \\
\hline \multicolumn{3}{|l|}{ Application rate } \\
\hline $\begin{array}{l}\text { pounds per acre per year } \\
{[(\text { lb/acre }) / y r]}\end{array}$ & 1.121 & $\begin{array}{l}\text { kilograms per hectare per year } \\
{[(\mathrm{kg} / \mathrm{ha}) / \mathrm{yr}]}\end{array}$ \\
\hline \multicolumn{3}{|l|}{ Leakance } \\
\hline foot per day per foot $[(\mathrm{ft} / \mathrm{d}) / \mathrm{ft}]$ & 1 & meter per day per meter \\
\hline inch per year per foot $[(\mathrm{in} / \mathrm{yr}) / \mathrm{ft}]$ & 83.33 & $\begin{array}{l}\text { millimeter per year per meter } \\
{[(\mathrm{mm} / \mathrm{yr}) / \mathrm{m}]}\end{array}$ \\
\hline
\end{tabular}

Temperature in degrees Celsius $\left({ }^{\circ} \mathrm{C}\right)$ may be converted to degrees Fahrenheit $\left({ }^{\circ} \mathrm{F}\right)$ as follows:

${ }^{\circ} \mathrm{F}=\left(1.8 \mathrm{x}^{\circ} \mathrm{C}\right)+32$

Temperature in degrees Fahrenheit $\left({ }^{\circ} \mathrm{F}\right)$ may be converted to degrees Celsius $\left({ }^{\circ} \mathrm{C}\right)$ as follows:

${ }^{\circ} \mathrm{C}=\left({ }^{\circ} \mathrm{F}-32\right) / 1.8$

Vertical coordinate information is referenced to the insert datum name (and abbreviation) here for instance, "North American Vertical Datum of 1988 (NAVD 88)."

Horizontal coordinate information is referenced to the insert datum name (and abbreviation) here for instance, "North American Datum of 1983 (NAD 83)."

Altitude, as used in this report, refers to distance above the vertical datum. 
*Transmissivity: The standard unit for transmissivity is cubic foot per day per square foot times foot of aquifer thickness $\left[\left(\mathrm{ft}^{3} / \mathrm{d}\right) / \mathrm{ft}^{2}\right] \mathrm{ft}$. In this report, the mathematically reduced form, foot squared per day $\left(\mathrm{ft}^{2} / \mathrm{d}\right)$, is used for convenience.

Specific conductance is given in microsiemens per centimeter at 25 degrees Celsius $\left(\mu \mathrm{S} / \mathrm{cm}\right.$ at $\left.25^{\circ} \mathrm{C}\right)$.

Concentrations of chemical constituents in water are given either in milligrams per liter (mg/L) or micrograms per liter $(\mu \mathrm{g} / \mathrm{L})$.

NOTE TO USGS USERS: Use of hectare (ha) as an alternative name for square hectometer $\left(\mathrm{hm}^{2}\right)$ is restricted to the measurement of small land or water areas. Use of liter $(\mathrm{L})$ as a special name for cubic decimeter $\left(\mathrm{dm}^{3}\right)$ is restricted to the measurement of liquids and gases. No prefix other than milli should be used with liter. Metric ton $(\mathrm{t})$ as a name for megagram $(\mathrm{Mg})$ should be restricted to commercial usage, and no prefixes should be used with it. 


\section{SI to Inch/Pound}

\begin{tabular}{|c|c|c|}
\hline Multiply & By & To obtain \\
\hline \multicolumn{3}{|l|}{ Length } \\
\hline centimeter $(\mathrm{cm})$ & 0.3937 & inch (in.) \\
\hline millimeter (mm) & 0.03937 & inch (in.) \\
\hline meter $(\mathrm{m})$ & 3.281 & foot $(\mathrm{ft})$ \\
\hline kilometer $(\mathrm{km})$ & 0.6214 & mile (mi) \\
\hline kilometer (km) & 0.5400 & mile, nautical (nmi) \\
\hline meter $(\mathrm{m})$ & 1.094 & yard (yd) \\
\hline \multicolumn{3}{|l|}{ Area } \\
\hline square meter $\left(\mathrm{m}^{2}\right)$ & 0.0002471 & acre \\
\hline hectare (ha) & 2.471 & acre \\
\hline square hectometer $\left(\mathrm{hm}^{2}\right)$ & 2.471 & acre \\
\hline square kilometer $\left(\mathrm{km}^{2}\right)$ & 247.1 & acre \\
\hline square centimeter $\left(\mathrm{cm}^{2}\right)$ & 0.001076 & square foot $\left(\mathrm{ft}^{2}\right)$ \\
\hline square meter $\left(\mathrm{m}^{2}\right)$ & 10.76 & square foot $\left(\mathrm{ft}^{2}\right)$ \\
\hline square centimeter $\left(\mathrm{cm}^{2}\right)$ & 0.1550 & square inch $\left(\mathrm{ft}^{2}\right)$ \\
\hline square hectometer $\left(\mathrm{hm}^{2}\right)$ & 0.003861 & $\begin{array}{l}\text { section ( } 640 \text { acres or } 1 \text { square } \\
\text { mile) }\end{array}$ \\
\hline hectare (ha) & 0.003861 & square mile $\left(\mathrm{mi}^{2}\right)$ \\
\hline square kilometer $\left(\mathrm{km}^{2}\right)$ & 0.3861 & square mile $\left(\mathrm{mi}^{2}\right)$ \\
\hline \multicolumn{3}{|l|}{ Volume } \\
\hline cubic meter $\left(\mathrm{m}^{3}\right)$ & 6.290 & $\begin{array}{l}\text { barrel (petroleum, } 1 \text { barrel }=42 \\
\text { gal) }\end{array}$ \\
\hline liter $(\mathrm{L})$ & 33.82 & ounce, fluid (fl. oz) \\
\hline liter $(\mathrm{L})$ & 2.113 & pint (pt) \\
\hline liter $(\mathrm{L})$ & 1.057 & quart (qt) \\
\hline liter (L) & 0.2642 & gallon (gal) \\
\hline cubic meter $\left(\mathrm{m}^{3}\right)$ & 264.2 & gallon (gal) \\
\hline cubic decimeter $\left(\mathrm{dm}^{3}\right)$ & 0.2642 & gallon (gal) \\
\hline cubic meter $\left(\mathrm{m}^{3}\right)$ & 0.0002642 & million gallons (Mgal) \\
\hline cubic centimeter $\left(\mathrm{cm}^{3}\right)$ & 0.06102 & cubic inch $\left(\right.$ in $\left.^{3}\right)$ \\
\hline cubic decimeter $\left(\mathrm{dm}^{3}\right)$ & 61.02 & cubic inch $\left(\right.$ in $\left.^{3}\right)$ \\
\hline liter $(\mathrm{L})$ & 61.02 & cubic inch $\left(\right.$ in $\left.^{3}\right)$ \\
\hline cubic decimeter $\left(\mathrm{dm}^{3}\right)$ & 0.03531 & cubic foot $\left(\mathrm{ft}^{3}\right)$ \\
\hline cubic meter $\left(\mathrm{m}^{3}\right)$ & 35.31 & cubic foot $\left(\mathrm{ft}^{3}\right)$ \\
\hline cubic meter $\left(\mathrm{m}^{3}\right)$ & 1.308 & cubic yard $\left(\mathrm{yd}^{3}\right)$ \\
\hline cubic kilometer $\left(\mathrm{km}^{3}\right)$ & 0.2399 & cubic mile $\left(\mathrm{mi}^{3}\right)$ \\
\hline
\end{tabular}




\begin{tabular}{|c|c|c|}
\hline cubic meter $\left(\mathrm{m}^{3}\right)$ & 0.0008107 & acre-foot (acre-ft) \\
\hline cubic hectometer $\left(\mathrm{hm}^{3}\right)$ & 810.7 & acre-foot (acre-ft) \\
\hline \multicolumn{3}{|l|}{ Flow rate } \\
\hline cubic meter per second $\left(\mathrm{m}^{3} / \mathrm{s}\right)$ & 70.07 & acre-foot per day (acre-ft/d) \\
\hline cubic meter per year $\left(\mathrm{m}^{3} / \mathrm{yr}\right)$ & 0.000811 & acre-foot per year (acre-ft/yr) \\
\hline $\begin{array}{l}\text { cubic hectometer per year } \\
\left(\mathrm{hm}^{3} / \mathrm{yr}\right)\end{array}$ & 811.03 & acre-foot per year (acre-ft/yr) \\
\hline meter per second $(\mathrm{m} / \mathrm{s})$ & 3.281 & foot per second (ft/s) \\
\hline meter per minute $(\mathrm{m} / \mathrm{min})$ & 3.281 & foot per minute (ft/min) \\
\hline meter per hour (m/hr) & 3.281 & foot per hour (ft/hr) \\
\hline meter per day $(\mathrm{m} / \mathrm{d})$ & 3.281 & foot per day (ft/d) \\
\hline meter per year (m/yr) & 3.281 & foot per year ft/yr) \\
\hline cubic meter per second $\left(\mathrm{m}^{3} / \mathrm{s}\right)$ & 35.31 & cubic foot per second $\left(\mathrm{ft}^{3} / \mathrm{s}\right)$ \\
\hline $\begin{array}{l}\text { cubic meter per second per } \\
\text { square kilometer }\left[\left(\mathrm{m}^{3} / \mathrm{s}\right) / \mathrm{km}^{2}\right]\end{array}$ & 91.49 & $\begin{array}{l}\text { cubic foot per second per square } \\
\text { mile }\left[\left(\mathrm{ft}^{3} / \mathrm{s}\right) / \mathrm{mi}^{2}\right]\end{array}$ \\
\hline cubic meter per day $\left(\mathrm{m}^{3} / \mathrm{d}\right)$ & 35.31 & cubic foot per day $\left(\mathrm{ft}^{3} / \mathrm{d}\right)$ \\
\hline liter per second $(\mathrm{L} / \mathrm{s})$ & 15.85 & gallon per minute (gal/min) \\
\hline cubic meter per day $\left(\mathrm{m}^{3} / \mathrm{d}\right)$ & 264.2 & gallon per day (gal/d) \\
\hline $\begin{array}{l}\text { cubic meter per day per square } \\
\text { kilometer }\left[\left(\mathrm{m}^{3} / \mathrm{d}\right) / \mathrm{km}^{2}\right]\end{array}$ & 684.28 & $\begin{array}{l}\text { gallon per day per square mile } \\
{\left[(\mathrm{gal} / \mathrm{d}) / \mathrm{mi}^{2}\right]}\end{array}$ \\
\hline cubic meter per second $\left(\mathrm{m}^{3} / \mathrm{s}\right)$ & 22.83 & million gallons per day (Mgal/d) \\
\hline $\begin{array}{l}\text { cubic meter per day per square } \\
\text { kilometer }\left[\left(\mathrm{m}^{3} / \mathrm{d}\right) / \mathrm{km}^{2}\right]\end{array}$ & 0.0006844 & $\begin{array}{l}\text { million gallons per day per } \\
\text { square mile }\left[(\mathrm{Mgal} / \mathrm{d}) / \mathrm{mi}^{2}\right]\end{array}$ \\
\hline cubic meter per hour $\left(\mathrm{m}^{3} / \mathrm{h}\right)$ & 39.37 & inch per hour (in/h) \\
\hline millimeter per year $(\mathrm{mm} / \mathrm{yr})$ & 0.03937 & inch per year (in/yr) \\
\hline kilometer per hour $(\mathrm{km} / \mathrm{h})$ & 0.6214 & mile per hour $(\mathrm{mi} / \mathrm{h})$ \\
\hline \multicolumn{3}{|l|}{ Mass } \\
\hline $\operatorname{gram}(\mathrm{g})$ & 0.03527 & ounce, avoirdupois (oz) \\
\hline kilogram (kg) & 2.205 & pound avoirdupois (lb) \\
\hline megagram $(\mathrm{Mg})$ & 1.102 & ton, short $(2,000 \mathrm{lb})$ \\
\hline megagram (Mg) & 0.9842 & ton, long $(2,240 \mathrm{lb})$ \\
\hline metric ton per day & 1.102 & ton per day (ton/d) \\
\hline megagram per day $(\mathrm{Mg} / \mathrm{d})$ & 1.102 & ton per day (ton/d) \\
\hline $\begin{array}{l}\text { megagram per day per square } \\
\text { kilometer }\left[(\mathrm{Mg} / \mathrm{d}) / \mathrm{km}^{2}\right]\end{array}$ & 2.8547 & $\begin{array}{l}\text { ton per day per square mile } \\
{\left[(\operatorname{ton} / \mathrm{d}) / \mathrm{mi}^{2}\right]}\end{array}$ \\
\hline megagram per year $(\mathrm{Mg} / \mathrm{yr})$ & 1.102 & ton per year (ton/yr) \\
\hline metric ton per year & 1.102 & ton per year (ton/yr) \\
\hline \multicolumn{3}{|l|}{ Pressure } \\
\hline kilopascal (kPa) & 0.009869 & atmosphere, standard (atm) \\
\hline kilopascal (kPa) & 0.01 & bar \\
\hline
\end{tabular}




\begin{tabular}{|c|c|c|}
\hline kilopascal (kPa) & 0.2961 & inch of mercury at $60^{\circ} \mathrm{F}$ (in $\mathrm{Hg}$ ) \\
\hline kilopascal (kPa) & 0.1450 & pound-force per inch (lbf/in) \\
\hline kilopascal (kPa) & 20.88 & pound per square foot $\left(\mathrm{lb} / \mathrm{ft}^{2}\right)$ \\
\hline kilopascal (kPa) & 0.1450 & pound per square inch $\left(\mathrm{lb} / \mathrm{ft}^{2}\right)$ \\
\hline \multicolumn{3}{|l|}{ Density } \\
\hline $\begin{array}{l}\text { kilogram per cubic meter } \\
\left(\mathrm{kg} / \mathrm{m}^{3}\right)\end{array}$ & 0.06242 & pound per cubic foot $\left(\mathrm{lb} / \mathrm{ft}^{3}\right)$ \\
\hline $\begin{array}{l}\text { gram per cubic centimeter } \\
\left(\mathrm{g} / \mathrm{cm}^{3}\right)\end{array}$ & 62.4220 & pound per cubic foot $\left(\mathrm{lb} / \mathrm{ft}^{3}\right)$ \\
\hline \multicolumn{3}{|l|}{ Energy } \\
\hline joule $(\mathrm{J})$ & 0.0000002 & kilowatthour (kWh) \\
\hline \multicolumn{3}{|l|}{ Radioactivity } \\
\hline becquerel per liter $(\mathrm{Bq} / \mathrm{L})$ & 27.027 & picocurie per liter $(\mathrm{pCi} / \mathrm{L})$ \\
\hline \multicolumn{3}{|l|}{ Specific capacity } \\
\hline $\begin{array}{l}\text { liter per second per meter } \\
{[(\mathrm{L} / \mathrm{s}) / \mathrm{m}]}\end{array}$ & 4.831 & $\begin{array}{l}\text { gallon per minute per foot } \\
{[(\mathrm{gal} / \mathrm{min}) / \mathrm{ft}]}\end{array}$ \\
\hline \multicolumn{3}{|l|}{ Hydraulic conductivity } \\
\hline meter per day $(\mathrm{m} / \mathrm{d})$ & 3.281 & foot per day (ft/d) \\
\hline \multicolumn{3}{|l|}{ Hydraulic gradient } \\
\hline meter per kilometer $(\mathrm{m} / \mathrm{km})$ & 5.27983 & foot per mile (ft/mi) \\
\hline \multicolumn{3}{|l|}{ Transmissivity* } \\
\hline meter squared per day $\left(\mathrm{m}^{2} / \mathrm{d}\right)$ & 10.76 & foot squared per day $\left(\mathrm{ft}^{2} / \mathrm{d}\right)$ \\
\hline \multicolumn{3}{|l|}{ Application rate } \\
\hline $\begin{array}{l}\text { kilograms per hectare per year } \\
{[(\mathrm{kg} / \mathrm{ha}) / \mathrm{yr}]}\end{array}$ & 0.8921 & $\begin{array}{l}\text { pounds per acre per year } \\
\text { [(lb/acre }) / y r]\end{array}$ \\
\hline \multicolumn{3}{|l|}{ Leakance } \\
\hline $\begin{array}{l}\text { meter per day per meter } \\
{[(\mathrm{m} / \mathrm{d}) / \mathrm{m}]}\end{array}$ & 1 & foot per day per foot $[(\mathrm{ft} / \mathrm{d}) / \mathrm{ft}]$ \\
\hline $\begin{array}{l}\text { millimeter per year per meter } \\
{[(\mathrm{mm} / \mathrm{yr}) / \mathrm{m}]}\end{array}$ & 0.012 & inch per year per foot $[(\mathrm{in} / \mathrm{yr}) / \mathrm{ft}]$ \\
\hline
\end{tabular}

Temperature in degrees Celsius $\left({ }^{\circ} \mathrm{C}\right)$ may be converted to degrees Fahrenheit $\left({ }^{\circ} \mathrm{F}\right)$ as follows:

${ }^{\circ} \mathrm{F}=\left(1.8 x^{\circ} \mathrm{C}\right)+32$

Temperature in degrees Fahrenheit $\left({ }^{\circ} \mathrm{F}\right)$ may be converted to degrees Celsius $\left({ }^{\circ} \mathrm{C}\right)$ as follows:

${ }^{\circ} \mathrm{C}=\left({ }^{\circ} \mathrm{F}-32\right) / 1.8$

Vertical coordinate information is referenced to the insert datum name (and abbreviation) here, for instance, “North American Vertical Datum of 1988 (NAVD 88)"

Horizontal coordinate information is referenced to the insert datum name (and abbreviation) here, for instance, "North American Datum of 1983 (NAD 83)"

Altitude, as used in this report, refers to distance above the vertical datum.

*Transmissivity: The standard unit for transmissivity is cubic foot per day per square foot times foot of aquifer thickness

$\left[\left(\mathrm{ft}^{3} / \mathrm{d}\right) / \mathrm{ft}^{2}\right] \mathrm{ft}$. In this report, the mathematically reduced form, foot squared per day $\left(\mathrm{ft}^{2} / \mathrm{d}\right)$, is used for convenience.

Specific conductance is given in microsiemens per centimeter at 25 degrees Celsius ( $\mu \mathrm{S} / \mathrm{cm}$ at $\left.25^{\circ} \mathrm{C}\right)$.

Concentrations of chemical constituents in water are given either in milligrams per liter (mg/L) or micrograms per liter $(\mu \mathrm{g} / \mathrm{L})$. 
NOTE TO USGS USERS: Use of hectare (ha) as an alternative name for square hectometer $\left(\mathrm{hm}^{2}\right)$ is restricted to the measurement of small land or water areas. Use of liter $(\mathrm{L})$ as a special name for cubic decimeter $\left(\mathrm{dm}^{3}\right)$ is restricted to the measurement of liquids and gases. No prefix other than milli should be used with liter. Metric ton (t) as a name for megagram (Mg) should be restricted to commercial usage, and no prefixes should be used with it. 


\title{
Metallogeny of the Great Basin: Crustal Evolution, Fluid Flow, and Ore Deposits
}

\author{
By Albert H. Hofstra' and Alan R. Wallace ${ }^{2}$ \\ 1-USGS, MS-973, Box 25046, Denver, C0 80225, <ahofstra@usgs.gov> \\ 2-USGS, Mackay School of Earth Sciences, MS-176, Reno, NV, 89557, <alan@usgs.gov>
}

\begin{abstract}
The Great Basin physiographic province in the Western United States contains a diverse assortment of world-class ore deposits. It currently (2006) is the world's second leading producer of gold, contains large silver and base metal $(\mathrm{Cu}, \mathrm{Zn}, \mathrm{Pb}, \mathrm{Mo}, \mathrm{W})$ deposits, a variety of other important metallic ( $\mathrm{Fe}, \mathrm{Ni}, \mathrm{Be}, \mathrm{REE}$ 's, $\mathrm{Hg}, \mathrm{PGE}$ ) and industrial mineral (diatomite, barite, perlite, kaolinite, gallium) resources, as well as petroleum and geothermal energy resources. Ore deposits are most numerous and largest in size in linear mineral belts with complex geology.

U.S. Geological Survey (USGS) scientists are in the final year of a research project initiated in the fall of 2001 to increase understanding of relations between crustal evolution, fluid flow, and ore deposits in the Great Basin. Because of its substantial past and current mineral production, this region has been the focus of numerous investigations over the past century and is the site of ongoing research by industry, academia, and state agencies. A variety of geoinformatic tools was used to organize, reinterpret, and display, in space and time, the large amounts of geologic, geophysical, geochemical, and hydrologic information deemed pertinent to this problem. This information, in combination with concentrated research on (1) critical aspects of the geologic history, (2) an area in northern Nevada that encompasses the major mineral belts, and (3) important mining districts and deposits, is producing new insights about the interplay between key tectonic events, hydrothermal fluid flow, and ore genesis in mineral belts.

The results suggest that the Archean to Holocene history of the Great Basin was punctuated by several tectonic events that caused fluids of different origins (sea water, basinal brine, meteoric water, metamorphic water, magmatic water) to move through the crust. Basement faults reactivated during these events localized deformation, sedimentation, magmatism, and hydrothermal fluid flow in overlying rocks to form mineral belts that contain ore deposits of different types and ages that are locally superimposed (demonstrating inheritance). Fluid flow in these systems also was influenced by the distribution of permeable lithologies and paleotopographic highs and lows. Hydrothermal fluids evolved from their initial chemistries towards compositions that reflect the $\mathrm{fO}_{2}$ and $f \mathrm{~S}_{2}$ buffering capacity of, and the ligands and metals present in, the rocks ( \pm older mineralization) through which they moved. In northern Nevada, where gold deposits are relatively common, carbonaceous, pyritic strata buffered fluids of diverse origins to $\mathrm{H}_{2} \mathrm{~S}$-rich compositions so
\end{abstract}


they could transport gold repeatedly over Paleozoic-Cenozoic time (convergent evolution). Ore formed where metal-laden fluids encountered effective physicochemical traps. Maps of Neogene basin fill and erosion surfaces identify areas where preexisting ore deposits have been progressively exposed or concealed. Comparisons with analogous terrains and deposit types in other parts of the world provide global context.

The initial findings and some of the databases, geologic maps, sections, reconstructions, hydrogeologic models, topical syntheses, regional overviews, short courses, field guides, and deposit comparisons produced by project staff and associated managers, contractors, and collaborators have been presented in numerous abstracts, symposia, USGS publications, and professional journals over the last 5 years (see the extensive bibliography). Notable among these was the 2005 Geological Society of Nevada symposium in Reno, Nevada, and the 2005 Geological Society of America annual meeting in Salt Lake City, Utah, where project results were presented to audiences from around the nation and world. The final results of the project will be submitted for publication in 2007 to appropriate USGS and professional journals. A special issue of GEOSPHERE, scheduled for publication in 2007, will be devoted to the results of this project and related work. This special issue will reach an international audience and be available worldwide on the internet.

Much of the research for this project has concentrated on areas that will receive the focused attention of the mining industry in the future. As such, the data and interpretations generated by this project have direct use for land-use managers in Federal, State, and local agencies. Improved hydrogeologic models developed by this project will considerably enhance ongoing and future water resource investigations in the region. The increased understanding of when, where, and how hydrothermal systems produce significant economic deposits has direct uses for mineral exploration and for future USGS mineral resource assessments in the Great Basin and other parts of the world.

\section{Introduction}

The Great Basin contains a large number of significant deposits for several commodities (Figure 1). It also contains some giants, such as the Carlin trend, which is the world's third largest gold camp; Bingham Canyon, one of the 10 largest porphyry copper systems; and Spor Mountain, the world's largest beryllium mine. Important molybdenum resources include Buckingham, Mt. Hope, and Pine Grove. The Great Basin is the world's third-leading producer of barite, from numerous deposits, and rare-earth elements, from the Mountain Pass mine. Production of lead, zinc, and silver from Utah porphyry systems rivals that of important mines in the Mississippi Valley region. Comstock, Tonapah, and Rochester in western Nevada are some of the country's largest silver mines. What is most remarkable is the large number of gold-bearing deposits of different types and ages that are present in this single region (Figure 2). Production from these deposits has made the United States the world's second leading gold producer. There are deposits of Devonian sedimentary exhalative (sedex) gold; Jurassic reduced intrusion-related gold;

Cretaceous porphyry, distal disseminated, and orogenic gold; Eocene porphyry, distal disseminated, and Carlin gold; and Cenozoic epithermal gold. The Great Basin also has more low-sulfidation epithermal gold deposits associated with bimodal magmatism and range-front faults than any other place in the world.

Many of these ore deposits occur in linear belts that are thought to be underlain by crustal structures produced by Neoproterozoic rifting. In the major mineral belts, basement faults are manifested by (1) growth faults, abrupt facies changes, and syngenetic ore deposits; (2) anomalous fold orientations and translational fault systems; and (3) igneous intrusions of Jurassic, Cretaceous, 
and Tertiary age. These relations suggested that crustal structures localized deformation, magmatism, and hydrothermal activity repeatedly over the complex Phanerozoic tectonic history of the region. They also prompted the following questions: How did mineral belts in the Great Basin originate and evolve through time? What role did the crystalline basement, terrigenous detrital sequence, carbonate sequence, and magmas play in the genesis of ore fluids? How did older structural features in these belts influence later episodes of mineralization? Were gold and other elements recycled? How do the mineral belts and deposits in this metallogenic province compare to those in other parts of the world?

To address these questions we needed: (1) high-quality framework information (geologic, geophysical, geochemical), which was readily available for the Great Basin; (2) a medium in which to interpret a variety of data sets (Geographic Information System [GIS] and relational databases); (3) 2- and 3-D geologic reconstructions for major episodes of mineral deposit formation on regional and/or district scales; (4) numerical models of fluid flow and mineral precipitation for areas and districts of interest; and (5) comparable information on important deposit types in the Great Basin and other parts of the world.

The overall goals of the Metallogeny of the Great Basin (MGB) project were to improve understanding of the tectonic events that triggered hydrothermal fluid flow and ore formation in the Great Basin, and to gain a better understanding of the origins and histories of the major mineral belts in northern Nevada. Specific project objectives included: (1) synthesis of key information generated over past decades in the Great Basin by the USGS, States, academia, and the mining and petroleum industries into digital maps, cross sections, and relational databases; (2) augmentation and combination of these maps, cross sections, and databases with new information from critical topical or geographic areas to address fundamental problems of ore genesis for a variety of mineral deposit types; (3) construction of a digital 3-D geologic model in northern Nevada that encompasses the major mineral belts; (4) construction of one or more detailed 2- and 3-D hydrogeologic models for large mining districts and geothermal areas; (5) reconstructions of the geology for important periods of ore formation on regional and/or district scales; and (6) numerical models of fluid flow, metal transport, and ore deposition. The project was designed to build a pyramid of knowledge using currently (2006) available information technology. At the base are topical maps and data on Great Basin geology and mineral deposits. These products were designed to capture the current state of knowledge on related topics and enter it into standard GIS and database software. For example, to understand Neogene metallogeny we need to assemble relevant information on geophysics, basins, faulting, magmatism, and epithermal ore deposits. In the middle of the pyramid is a regional geologic model for an area in northern Nevada that encompasses the major gold belts. We have been constructing maps, sections, and flow models for this area. At the top of the pyramid are a series of geologic, fluid flow, and chemical models for mining districts of interest. The yellow, orange, and magenta lines on Figure 2 outline study areas for the Great Basin, northern Nevada gold belts, and select mining districts. Figure 3 is an example of a topical map database product. Figure 4 is a revised digital geologic map of Nevada. Figure 5 shows some of the regional cross sections in the northern Nevada study area. Figure 6 is an example of a 3-D hydrogeologic model, and Figure 7 shows examples of 2-D flow models of fluid flow.

To fulfill project objectives, a large team of experts and the full laboratory capabilities of the USGS collaborated on this world class metallogenic province. Survey personnel that contributed to the MGB project included management (Constance Nutt and Peter Vikre); emeritus geoscientists (Harry Cook, Anita Harris, Charles Naeser, J. Thomas Nash, F.G. "Barney" Poole, Ted Theodore, and Charles Thorman); USGS staff scientists (Carl Abston, William Christiansen, Paul Denning, Sharon Diehl, Jeff Doebrich, Edward du Bray, Julie Dumoulin, Poul Emsbo, James 
Evans, Robert Fleck, Jonathan Glen, Mathew Granitto, V.J.S. "Tien" Grauch, Albert Hofstra, Keith Howard, Alex Iriondo, David John, Michael Kunk, Gary Landis, Karen Lund, Daniel Miggins, Lavinia Mills-Herring, Lisa Morgan, Robert Morin, Barry Moring, Thomas Moore, Benita Murchey-Setnicker, David Ponce, Wayne Premo, Barnaby Rockwell, Brian Rodriguez, Robert Rye, Jay Sampson, Donald Shamp, Sharon Smith, Lawrence Snee, Donald Sweetkind, Janet Tilden, Alan Wallace, Jackie Williams, Douglas Yager, and Ross Yeoman); a Mendenhall postdoctoral fellow (Joseph Colgan); student employees (Logan Hackett, Carl Bern); and volunteers (Julianne McCabe, Katherine Fifarek). The project also recruited a number of contractors and cooperative researchers (Samal Abani, Robert Blodgett, Elizabeth Crafford, Richard Fifarek, Kenneth Hickey, Jared Morrow, Mark Person, Ning Zhang) that were critical to its success.

We wish to acknowledge and thank the individuals listed above as well as their numerous collaborators and coauthors for their valuable contributions. The purpose of this report is to summarize the progress made towards project goals and to provide a bibliography of USGS research products on topics relevant to the metallogeny of the Great Basin. This project has lead to a vastly improved understanding of the fundamental controls on the genesis of ore deposits and the roles of rock packages, magmatism, crustal structures, fluid flow, and inheritance in this worldclass gold province. Additional information on past and current Mineral Resources Program projects is available at the http://minerals.er.usgs.gov/usgs/.

\section{Relation to previous and current USGS projects in the region}

The Metallogeny of the Great Basin (MGB) project builds on the results of two previous 5year Mineral Resources Program projects in the Great Basin. The Western Region Gold project culminated in a two-part Special Issue of Economic Geology devoted to gold deposits in northern Nevada (John and others, 2003b; Hofstra and others, 2003 and articles therein). The Humboldt River Basin Assessment project published a USGS Bulletin (Wallace and others, 2004b) that evaluated the metallic mineral-resource potential of a large area in northern Nevada and produced related publications (e.g., Nash, 2004; Yager and Folger, 2005; Ludington and others, 2006). The current MGB project was inspired by the Department of Energy/Water Resources Discipline (DOE/WRD) Death Valley Hydrogeologic Models project (Figure 2) that generated 2- and 3-D interpretations of the geology to frame simulations of ground water flow systems (e.g., Sweetkind and others, 2001; Potter and others, 2002). The MGB project also has had synergies with several other USGS projects in the Great Basin and adjacent areas, and some investigations were jointly supported by two or more projects and/or involved some of the same individuals. Examples include: the Western Region Surveys and Analysis project that produced digital datasets on mineral deposits, geology, geophysics, and geochemistry (e.g., Nutt and Ludington, 2003; Ludington and others, 2005, 2006); the Sources of Industrial Minerals in Western States project (e.g., Bliss and others, 2002, Koski and Hein, 2003; Rytuba and others, 2003; Wallace, 2003d, 2004); the Metals in Brine and Petroleum project that evaluated the role of seafloor discharges of brine and petroleum in the formation of syngenetic ore deposts in sedimentary basins (e.g., Emsbo, 2004; Hofstra and Emsbo, 2005; Johnson and Emsbo, 2004); the Geochemical and Isotope Studies of the Evolution of Ore Deposits project that has characterized the stable isotope geochemistry of sulfate minerals in igneous and hydrothermal systems, the gas and noble gas isotope composition of magmatic hydrothermal alunite, and the source of salt in hydrothermal fluids from diverse hydrothermal systems (Rye, 2005; Landis and Rye, 2005; Hofstra and Emsbo, 2005); the Resources and Hazards of Hydrothermal Systems in Cascades Volcanoes project that has elucidated controls on alteration and metallogenesis in the Oligocene-Quaternary Cascades arcs (e.g., John and others, 2003a); a project that investigated the origin, tectonic relations, and manifestations of the Yellowstone 
hotspot track (e.g., Morgan and others, 2004; Pierce and others, 2004); a project that evaluated the coupling of mechanical, thermal, chemical and hydraulic phenomena in ore formation (e.g., Berger and others, 2005); allied investigations by our Western and Central Region Mineral Resources Team Chief Scientists Connie Nutt and Peter Vikre (Nutt and Hofstra, in press; Vikre and others, 2003, 2005a,b, in press); and related investigations by colleagues on other projects (e.g., Church and others, 2005). The MGB project also complements two groundwater investigations in the Great Basin: the Hydrogeologic Framework of Aquifer Systems in the Desert Southwest project that addresses ground-water availability (Chuang and others, 2003; Howard and others, in press) and the Basin and Range Carbonate Aquifer System Study (BARCASS) project that is conducting research on regional ground-water flow systems in Nevada and potential impacts from future ground-water pumping (http://nevada.usgs.gov/barcass/index.htm). Several emeritus scientists (Harry Cook, Anita Harris, Charles Naeser, J. Thomas Nash, F.G. "Barney" Poole, Ted Theodore, and Charles Thorman) were supported by the MGB project to aid completion of their maps, reports, and syntheses. The project also supported the initial work of Mendenhall postdoctoral research fellow Joe Colgan on extensional faulting and uplift cooling histories of critical areas in the Great Basin.

\section{Synergies with others}

Related work and collaborative research with the Nevada Bureau of Mines and Geology (NGMB; http://www.nbmg.unr.edu/), particularly the online publication of geologic maps and data on wells, ore deposits/mining districts, igneous rocks, isotopic dates, and faults, has been an important foundation of this project. Collaborations with students and professors from several academic institutions and industry geologists have also been of critical importance.

The MGB project endorsed three Mineral Resources Program External Research Proposals that were awarded in 2005 and 2006. James Saunders (Auburn University) is investigating the timing and duration of bimodal magmatism and hydrothermal activity in the vicinity of the bonanza-grade, low-sulfidation Sleeper Au-Ag deposit using laser ${ }^{40} \mathrm{Ar} /{ }^{39} \mathrm{Ar}$ methods. Kenneth Hickey and Richard Tosdal (Mineral Deposits Research Unit, University of British Columbia) are documenting paleothermal anomalies around Eocene Carlin-type gold districts in Nevada using apatite and zircon fission-track methods. Jean Cline (University of Nevada, Las Vegas) and John Muntean (NBMG) are tracing fluid sources and flow paths in the Getchell Trend.

\section{Milestones}

This project has had a number of important milestones. At the 2002 Geological Society of America meeting in Denver, the USGS and Society of Economic Geologists (SEG) jointly sponsored a topical session on "Diverse origins of sedimentary rock-hosted disseminated gold deposits" to gain an international perspective (Spain, Macedonia, Australia, New Zealand, Indonesia, China, and the United States) on the settings, attributes, fluid sources, and processes of ore formation. Two invited overview papers on epithermal precious and base metal deposits and Carlin-type gold deposits, coauthored by David John and Albert Hofstra, respectively, were published in the 100th Anniversary Volume of SEG (Simmons and others, 2005; Cline and others, 2005). At the 2005 Geological Society of Nevada symposium convened in Reno every 5 years, project results were presented to an audience of international to local mining, exploration, and research geologists. Contributions by project personnel, contractors, and collaborators accounted for 15 of the 37 contributions on the geology of the Great Basin region that were presented at this meeting. At the 2005 Geological Society of America annual meeting in Salt Lake City, two USGS- 
sponsored topical sessions on "Great Basin Tectonics and Metallogeny" were convened to familiarize a national to regional audience with project research and to gain input from regional experts. An outgrowth of this meeting will be the publication of final reports in a special issue of GEOSPHERE, edited by the project chiefs - Albert Hofstra and Alan Wallace - devoted to "Great Basin Tectonics and Metallogeny" in the latter part of 2006 and 2007. GEOSPHERE is an ideal place to publish project research because it is an electronic journal designed to handle a wide variety of conventional and unconventional reports, maps, sections, databases, and animations. It also is available worldwide on the internet, thereby ensuring that the results of the project will be available globally. As appropriate, other final reports will be submitted in 2007 for publication in USGS and professional journals.

\section{Database development}

One of the major challenges of this project has been to determine how to organize data in ways that have geologic meaning and application Figure 8 shows the hierarchical nature of geologic information. We are working to compile and organize information on the age, location, and attributes of geologic entities, that range in scale from a mineral in a sample to progressively larger map units, and to link these data through the various scales. For example, noble gas data on olivine may be from a sample of basalt collected from a dike that fed a flow that is part of a volcanic center in the northern Nevada rift that is part of a large igneous province related to the Yellowstone hotspot track. Database development has moved forward on several fronts. This effort benefited from concurrent work by USGS and external research groups associated with the CHRONOS (www.chronos.org) geoinformatic project that are developing ontologies and databases for geologic maps and igneous and sedimentary rocks. Initial reports include an overview on database design concepts and schema for the project (Yager and Hofstra, 2004), a preliminary hierarchical database for bimodal igneous rocks (Yager and others, 2005), an integrated National Aeronautics and Space Administration/Goddard Space Flight Center and USGS rock magnetic database (Nazrova and Glen, 2004), a conodont database for Nevada (Crafford and Harris, in press), and a fossil database design (N. Zhang and R. Blodgett, unpublished administrative report for A.H. Hofstra). An important ingredient in the igneous rock database has been geochronologic data compiled by C.D. Henry at the NBMG. Likewise, conodont fossil age control produced by USGS emeriti, Anita Harris and Charles Sandberg, has been of critical importance for sedimentary rocks. Database design, population, and/or implementation are continuing on a master igneous rock database (D. Yager and others), a fossil and sedimentary-rock database (N. Zhang and others), and an ore-deposit database (A. Hofstra and others).

\section{Geologic maps}

GeoLogic Services was contracted to produce a revised, 1:250,000-scale, digital geologic map of Nevada (Figure 4) to frame the development of regional cross sections and 3-D models in northern Nevada (Crafford, 2005, in press). Important refinements to the map include the addition of conodont ages and color alteration indices (CAI; Crafford and Harris, 2005, in press) and revised pluton ages and compositions (du Bray and Nash, 2005; du Bray and others, in press).

Several 1:24,000 scale maps of key areas also were produced by project staff (Willow Creek Reservoir and Willow Creek Reservoir SE Quadrangles-Wallace, 2003a,b; Verdi Peak Quadrangle-Howard and MacCready, 2004; Mule Canyon Quadrangle-John and Wrucke, 2003; Cedars Quadrangle- Moore and others, in press; Big Bald Mountain Quadrangle and part of the Tognini Quadrangle-Nutt and Hart, 2004; Minden Quadrangle-Ramelli and others, 2003; Vigo NE 
Quadrangle-Scott and Harding, in press; Beaver Peak Quadrangle- Theodore and others, 2003; Oxley Peak Area-Thorman and others, 2003; Unity Reservoir Quadrangle-Evans, 2003; and Huntsman Ranch Quadrangle-Wallace and others, in press).

\section{Geophysics}

A geophysical terrane map of the entire Great Basin region and adjacent areas (Glen and others, 2004a) outlines gravity and magnetic anomalies and provides information on their attributes and inferred sources (Figure 3). New gravity data have been collected to fill gaps and refine models of the thickness of basin fill in important mineral districts, along regional cross sections, and between ranges across the northern Nevada study area (e.g., Sweetkind and others, 2005a,b; Tilden and others, 2005; Figure 6). Variations in the thickness of basin fill provide additional evidence of range tilt domains across the Great Basin. The basement gravity anomaly in northcentral Nevada has been better characterized and postulated to represent either a deep crustal discontinuity or mid- to subcrustal mafic intrusions associated with the Northern Nevada Rift (Ponce and Glen, 2005). Gravity and magnetic data also have been used to map regional-scale fractures intruded by bimodal magmas associated with the Yellowstone hot spot in the northern Great Basin and adjacent areas of Washington, Oregon, and Idaho (Evans and others, 2004; Coe and Glen, 2004; Glen and Ponce, 2002; Glen and others, 2003, 2004b). These studies also show that preexisting crustal structures influenced the distribution of bimodal magmatism in the northern Great Basin and southeast Oregon. PRJ, Inc. was contracted to provide geophysical interpretations based on their proprietary (high-resolution) aeromagnetic surveys of intrusions, volcanic rocks, and faults along some of the regional cross sections in northern Nevada (unpublished administrative report for A.H. Hofstra). Geophysical data were used together with geologic evidence and variations in the isotopic compositions of igneous intrusions to show that deep crustal structures influenced Paleozoic tectonics, magmatism, and the alignment of ore deposits in some of the major mineral belts of northern Nevada (Crafford and Grauch, 2002; Grauch and others, 2003). Emsbo and others (2006) go on to suggest that the vast endowment of gold in these mineral belts results from the protracted interplay of orogenic, basinal, and hydrothermal processes along reactivated basement faults near the lithospheric boundary produced by the Neoproterozoic breakup of Rodinia.

Magnetotelluric (MT) soundings acquired between 1994 and 2005 in northern Nevada were modeled to detect the presence, or absence, and orientations of deep penetrating faults in the vicinity of recognized mineral belts in northern Nevada. New MT surveys were conducted to map the position of the east-west suture zone between the Archean Wyoming province and the Paleoproterozoic Mojave province in western Utah and northeast Nevada that localized the giant Bingham Canyon porphyry copper deposit (Rodriguez and Williams, 2002, 2005; Rodriguez and others, 2005, Wannamaker and others, 2002; Williams and Rodriguez, 2003, 2004, 2005). A surprising result of the MT modeling in northern Nevada is that most of the crustal faults detected are at an oblique angle to the strike of the mineral belts. This result may be caused by the dilation of oblique faults that intersect, or occur within, the mineral belts and is consistent with the strike of some ore-controlling faults at the surface. The new MT surveys suggest that the ArcheanProterozoic suture zone veers to the north just east of Wells, Nevada. This interpretation indicates that only the northeastern corner of Nevada is underlain by Archean crust, and that the remainder of northeastern Nevada is underlain by Proterozoic crust. Supporting evidence for this interpretation is provided by SHRIMP U-Pb ages of inherited zircons and $\mathrm{Sr}$ and $\mathrm{Nd}$ isotopic signatures of Mesozoic and Cenozoic intrusions in the Northern Ruby Mountains-East Humboldt Range core complex (Premo and others, 2005) that indicate it is underlain by siliciclastic rocks derived from 
the craton and/or Proterozoic crust. Because the composition of the deep crust may have an important influence on magma generation and on deeply circulating fluids, this distinction between crusts of different ages and character may prove to be critical for developing regional ore-genesis models.

\section{Geochemistry}

Data on the $\mathrm{Pb}, \mathrm{Sr}$, and $\mathrm{Nd}$ isotopic composition of igneous and sedimentary rocks and ore deposits are being compiled to identify basement features and refine understanding of the source of these elements in magmas and hydrothermal systems (Grauch and others, 2003; Premo and others, 2005).

Major-oxide and trace-element analyses of intrusive and extrusive igneous rocks made by the USGS over past decades have been gathered, locations verified, and descriptions improved for inclusion in a master igneous-rock database currently (2006) in preparation (D. Yager and others). USGS data on intrusions also has been combined with data from other sources to build a comprehensive data set for intrusions in the northern Nevada study area (du Bray and Nash, 2005; $\mathrm{du}$ Bray and others, in press). The ability of remotely sensed multispectral thermal infrared data to map variations in the silica content of igneous rocks has been demonstrated in the Hiller Mountains (Hook and others, 2005). USGS trace-element data on variably altered and mineralized rocks have been gathered, enhanced, and compared to trace-element data on soil and sediment (Yager and Folger, 2005) to evaluate the geochemical expression of significant base- and precious-metal deposits in these media (Granitto and others, 2005). In this study, factor analysis was used to identify element associations in the data related to major rock and deposit types.

\section{Neoproterozoic to Devonian passive margin}

Studies are in progress on the style of extensional faulting during Rodinian rifting and the nature of Neoproterozoic-Middle Cambrian siliciclastic sedimentary rocks in the Great Basin (K. Lund). A major effort has been made to improve understanding and digital datasets pertinent to Paleozoic rocks because they host a large proportion of the metallic mineral resources in the Great Basin and in some deposits were important sources of elements in the ores. Conodont age and CAI maps and database of Nevada have been prepared to validate the age of map units and facilitate revisions and to identify thermal anomalies related to deformation, magmatism, and hydrothermal activity (Crafford and Harris, 2005, in press). A bibliography of paleontological data has been compiled (Blodgett and others, in press) and a fossil database constructed to house information on the fossil age and environment of sedimentary rocks in the Great Basin that can be served over the web (N. Zhang and R. Blodgett unpublished administrative report for A.H. Hofstra). Because so many syngenetic and epigenetic ore deposits occur in Devonian and Mississippian rocks, the fossil database is currently being populated with information on fossils of that age to aid reconstructions of basin architecture over that time period (e.g., Emsbo and Morrow, 2005). Data from published and unpublished, described, and dated sections are being transformed into a database to enable digital displays of unit lithology, thickness, facies, and paleogeography (e.g., McCabe and others, 2005; F.G. Poole and others, in prep.). A sedimentary rock database is also under construction to integrate fossil, lithology, facies, and sequence information over a range of scales. The sedimentary facies and sequence stratigraphy of Paleozoic carbonate rocks have been characterized along an east-west profile across the Great Basin, which enables us to evaluate the influence of facies and unconformities on the localization of ore (Cook and Corboy, 2004; Cook, 2005, 2006). This study and a companion study by Crafford (2005) show that most Carlin-type gold deposits are located 
where crustal faults intersect slope-facies rocks near the carbonate platform margin. The vast majority of the gold in Carlin-type deposits is hosted in Devonian rocks. A report on the chemical and isotopic composition of barren and mineralized sections of the Devonian Popovich Formation is in preparation (W. Christiansen and A. Hofstra). Rocks of Devonian age also record episodes of synsedimentary faulting that produced abrupt facies changes and localized discharges of metal and nutrient-laden basinal brines and petroleum; these fluids formed metalliferous black shales and sedex gold, zinc and barite resources (Emsbo and others, 2002; Hofstra and Emsbo, 2005; Emsbo and Morrow, 2005; Johnson and Emsbo, 2004). A number of smaller sedex barite and Carlin-type gold deposits occur in the overlying Carboniferous foreland basin sequence. Basinal brines also produced small Mississippi Valley-type (MVT) lead-zinc deposits and occurrences, such as those hosted in Mississippian rocks in the Good Springs district. Brine migration pathways through permeable carbonate strata and faults are marked by the formation of hydrothermal zebra dolomite (Diehl and others, 2005a,b). Brines were produced by the evaporation of seawater (Hofstra and Emsbo, 2005) in silled basins when the Great Basin was at equatorial paleolatitudes (Berger and Theodore, 2005a,b) and evolved to become hot ore fluids as they circulated through underlying sedimentary and crystalline rocks (Church and others, 2005). The distribution and field relations between zebra dolomite, sedex, and MVT deposits in the Great Basin suggest that brine migration was widespread and occurred in response to two tectonic events: Devonian extensional faulting and Mississippian contraction associated with the Antler orogeny (Diehl and others, 2005a,b). A global context for sedex barite is provided by a comparison of deposits in the world's three largest barite producing regions in the Great Basin, China, and India (Clark and others, 2004).

\section{Late Paleozoic and Mesozoic contraction}

An important improvement of the new Nevada State digital geologic map over earlier maps is a revised grouping of colloquial formations and units into coherent tectono-stratigraphic terranes and foreland-basin sequences associated with major orogenies in the Great Basin (Crafford, 2005, in press). A digital map of large-scale folds produced by these orogenic events in northern Nevada is currently (2006) in preparation (T. Moore). Important manifestations of these tectonic events have been documented by several studies. Recognition of Late Devonian and Mississippian arkose derived from an unidentified granitic source terrane adds a new dimension to the Antler orogeny (Ketner and others, 2005). Thermal metamorphism of carbonaceous material in sedex horizons in the Carlin trend during the Antler orogeny generated petroleum containing elevated levels of gold (Emsbo and Koenig, 2005). Field relations indicate that a post-Antler episode of thrust faulting in the Carlin trend was synchronous with deposition of the Pennsylvanian and Permian Strathearn Formation (Theodore and others, 2004). Identification of a new chonetoidean brachipod fossil in the southern Shoshone range improves stratigraphic correlations in the Permian overlap assemblage (Rachebouf and others, 2004). The time and space distribution of deformation and sedimentation associated with the Jurassic Elko orogeny is described by Thorman and Peterson (2003). The importance of Late Paleozoic and Mesozoic structural inversion along reactivated basement faults and its role in the formation of the antiforms that focused fluid flow and large concentrations of Carlin-type gold deposits is shown by Hofstra (2005b) and Emsbo and others (2006). Related work by J.L. Muntean at the NBMG and his colleagues demonstrates that Carlin-type gold deposits are localized along inverted Paleozoic normal faults. The influence of low-angle and bedding-parallel faults produced by these orogenic events on lateral fluid flow and the localization of ore in Carlintype deposits was described by Nutt and Thorman (2005). 


\section{Mesozoic and Cenozoic arc magmatism and pluton-related ore deposits}

The space-time-compositional evolution of intrusive rocks in the Great Basin is being synthesized to clarify the roles of magma evolution and episodes of magma emplacement in the formation of a variety of pluton-related mineral deposits and to improve digital geologic maps of Utah and Nevada (Nutt and Ludington, 2003; du Bray and Nash, 2005; du Bray and others, in press; Crafford, in press). This work also has contributed to the development of a metamorphic map of California (Day and others, 2003). Detailed studies of Cretaceous and Tertiary intrusions in the Ruby Mountains-East Humboldt Range have enhanced understanding of magma petrogenesis, crustal contamination, and emplacement mechanisms at mid-crustal levels during contraction and extension (Howard and others, 2004a,b; Lee and others, 2003; Snoke and others, 2004; Premo and others, 2005). Complementary studies of Eocene intrusions in the Carlin trend and adjacent areas in north central Nevada have been conducted by C. Henry and M. Ressel at the NBMG and University of Nevada, Reno. Studies of Jurassic intrusions and ore deposits in the Bald Mountain district indicate it is the first reduced intrusion-related gold deposit to be recognized in the Great Basin (Nutt and Hofstra, in press; E. du Bray and T. Nash, in prep.). The role of magmatic versus non-magmatic fluids in the formation of Jurassic reduced intrusion-related gold deposits (Nutt and Hofstra, in press), Eocene porphyry, skarn, vein, replacement, and distal disseminated deposits (Battle Mountain-McGibbon and Theodore, 2002; Park City-John, in press; Bingham CanyonCunningham and others, 2002, 2003, 2005), Eocene Carlin-type gold deposits and younger epithermal deposits (see below) have been addressed on a district-by-district basis and for different deposit types in several publications.

\section{Paleogene basins, magmatism, faulting, and ore deposits}

Information on Paleogene topography, faulting, and extension-related folds is provided by studies of Eocene basins in the northern Independence Range and exposures of fluvial and lacustrine rocks in the Alligator Ridge district and other areas in the eastern Great Basin (e.g., Howard and Nutt, 2005; Nutt and Howard, 2003; Nutt, 2002). Related investigations on the Eocene Elko basin and adjacent topographic highs in the vicinity of the Carlin trend and Jerritt Canyon district by S.R. Haynes, K.A. Hickey, and R.M. Tosdal at the University of British Columbia have identified a pulse of Eocene extensional faulting that is coeval with Carlin-type gold mineralization. Information on Late Cretaceous-Paleogene exhumation and development of an Eocene erosion surface, provided by apatite fission-track dating and the distribution of Eocene basins, is currently (2006) being assembled (K. Hickey and others, in prep.). These studies influence hydrogeologic models developed for the Carlin trend (e.g., Person and others, 2005).

Subsequent large-magnitude extension in the Ruby Mountains and development of several other metamorphic core complexes and tilted slabs provide important exposures of the upper and middle crust (Howard, 2002, 2003, 2005). These rocks place constraints on the attributes of older thrust faults and folds, igneous intrusions, and Neogene extension that frame development of regional cross sections (e.g., Sweetkind and others, 2005a,b) and constrain hydrogeologic models for neighboring districts, such as the Carlin trend mentioned above.

Understanding of the distribution, composition, and age of calc-alkaline volcanic centers, calderas, and ash-flow tuffs has been improved by a number of the 1:24,000 scale maps listed earlier. A study of the widespread late Eocene Caetano Tuff has defined the age and attributes of two distinct eruptive units and the location of a source caldera in an east-west volcano-tectonic trough (John and Henry, 2005). Related investigations of calderas and ash-flow tuffs by C. Henry and J. Faulds at the NBMG and M. Best and E. Christiansen at Brigham Young University are 
enhancing understanding of regional volcanology, topographic relief, and the distribution of paleovalleys across the Great Basin, as well as understanding of the style of subsequent faulting within and east of the Walker Lane in the western Great Basin. The paucity of epithermal ore deposits associated with the southward-sweeping patterns of Eocene-Miocene calc-alkaline volcanism in the Great Basin and the abundance of deposits associated with the ancestral Cascades magmatic arc have been described in a number of overviews (Ludington and John, 2002; John, 2003, 2005; and John and others, 2005) and deposit/district studies mentioned below.

Preliminary syntheses (Cline and others, 2004; Hofstra, 2002a, 2004, 2005a; Thorman, 2002) and an invited overview paper on the role of older geologic features, Eocene geologic setting, and origin of Carlin-type gold deposits in northern Nevada, with a comprehensive database on the geology and attributes of deposits in every district/trend, was published in the 100th Anniversary Volume of Economic Geology (Cline and others, 2005). A related overview on stratabound ore bodies in several Carlin-type districts suggests these may be of Paleozoic age and syngenetic origin (Berger and Theodore, 2005a,b). Another important overview suggests that successive reactivation of faults and superposition of hydrothermal systems in mineral belts above a lithospheric boundary explains the huge endowment of gold in northern Nevada (Emsbo and others, 2006). Detailed studies of the attributes and origin of the Devonian Rodeo sedex gold deposit in the Carlin trend (Emsbo and others, 2002), Jurassic reduced intrusion-related gold deposits in the Bald Mountain district (Nutt and Hofstra, 2002, in press), and Eocene Carlin-type gold deposits in the Alligator Ridge, Getchell, and Gold Bar districts (Nutt and Hofstra, 2002; Cline and others, 2002a,b, 2003a,b; Yigit and others, 2006) were critical to development of these interpretations.

Complementary studies of the other types of sedimentary rock-hosted disseminated gold (SRHDG) deposits in the Great Basin (Samal and others, 2005; Cunningham and others, 2002, 2003, 2005; Emsbo and others, 2002, 2005; McGibbon and Theodore, 2002; Theodore and Kotlyar, 2002; Nutt and Hofstra, 2002, in press) and elsewhere in the world (Christiansen and others, 2002; Daliran and others, 2002; Percival and Hofstra, 2002a,b; Turner and others, 2002) together with research on the large number of Carlin-type and other sedimentary rock-hosted gold deposits in China (Goldfarb and others, 2004; Hofstra and others, 2005a,b,c; Zhang and others, 2005) provide global context and show the ability of reduced, carbonaceous, pyritic sedimentary rocks to buffer fluids from different sources to $\mathrm{H}_{2} \mathrm{~S}$-rich compositions that facilitate the transport and deposition of gold (convergent evolution). Preliminary overviews on the diverse origins of sedimentary rockhosted disseminated gold deposits around the world (Hofstra, 2002b, 2004) contributed to the model developed for Nevada Carlin-type deposits cited above, and a thorough overview paper on these deposits is currently (2006) in preparation (A. Hofstra and P. Emsbo).

\section{Neogene basins, magmatism, faulting, and epithermal ore deposits}

Neogene basin and lake development, bimodal magmatism associated with crustal extension and mantle upwelling (such as the Yellowstone hot spot), Basin and Range block faulting, and climate evolution resulted in the formation of numerous low-sulfidation gold, silver, and mercury deposits, the world's largest beryllium deposit (Spar Mountain), significant molybdenum, uranium, and gallium resources, large diatomite deposits, numerous geothermal areas, and important ground water resources (e.g., Rytuba and others, 2003; Wallace 2005a,b; Wallace and others, 2004a). These processes also led to the present configuration, exposure, and concealment of both pre-Neogene and Neogene mineral deposits. Evaluating and "stripping away" the effects of processes that took place during the Neogene is the first step in reconstructing the early Tertiary and older mineralizing environments and metallogenesis. 
Detailed studies of the Miocene Humboldt Formation and younger fluvial and lacustrine deposits constrain the timing of Basin and Range faulting and reveal changing patterns of basin accumulation and erosion between $16 \mathrm{Ma}$ and the Present related to the formation and removal of volcanic and tectonic dams (Wallace, 2002, 2005a,b; Wallace and others, 2004b). As a consequence, mineral deposits in northeastern Nevada are being exhumed while those in northwestern Nevada are being concealed. Resulting exposure levels and basin attributes influence the supergene oxidation of sulfide ores, estimates of the depth of cover over concealed deposits, and evaluations of ground-water resources.

The origin, processes, and patterns of volcanism and tectonism that were inherited from preexisting structures and caused by the Yellowstone hot spot track, and their geophysical expressions have been mapped and described (Glen and Ponce, 2002; Glen and others, 2003, 2004b, Morgan and others, 2004; Pierce and others, 2004; Rytuba and others, 2004). The distribution, age, and geochemistry of bimodal volcanic rocks in the Miocene northern Nevada rift and other volcanic centers in northern Nevada have been assembled into a database, facilitating studies of their petrogenesis and their relation to basement features and low sulfidation Au-Ag deposits (John, 2005; John and others, 2002, 2005; Ponce and Glen, 2005; Yager and others, 2005). Studies of the mid-Miocene Steens Mountain volcanic field document the early magmatic evolution of the hot spot and provide a detailed record of magnetic reversals of wide applicability (Jarboe and others, 2003, 2004). The neighboring intermediate composition Santa Rosa-Calico eruptive products of about the same age are inferred to result from interactions between mantle- and crustal-derived materials (Brueseke and others, 2003). The origin of paleomagnetic fabics in igneous rocks also has been assessed (Plenier and Glen, 2004). Studies of the Pliocene Coso volcanic field in southeastern California document the age, compositional evolution, and kinematics of subsequent block rotations along the western side of the Great Basin (Pluhar and others, 2003a,b, 2004).

Studies of the geology, age, and attributes of low-sulfidation gold-silver deposits in northern Nevada document the similarities and differences among such deposits that formed during the past 16 million years. Deposits studied in detail included Mule Canyon (John and Hofstra, 2002), Midas (Leavitt and others, 2003), Ivanhoe (Wallace, 2003c), Seven Troughs (Hudson and others, 2005, 2006) and other deposits in the Lovelock area (John and Muntean, 2006), and Florida Canyon (Samal and others, 2005). Some of these are located along or near the northern Nevada rift or subparallel magnetic anomalies farther west; ages differ, in places significantly, but the deposits have many features in common, indicating that many ore-forming processes were independent of time.

In the western part of the Great Basin, volcanic centers along the ancestral Cascades magmatic arc and the Walker Lane dextral shear zone controlled the localization of several Miocene porphyry-epithermal systems analogous to those being studied in the present Cascades arc (Ludington and John, 2002; John and others, 2003a). In the Virginia Range, multiple episodes of magmatism, acid-sulfate alteration, and low-sulfidation precious-metal mineralization were documented (Vikre and others, 2003), and, at Goldfield, the age and composition of magmatic hydrothermal alunites were characterized (Vikre and others, 2005a,b). The attributes of these and many other epithermal systems in the area suggest they are the shallow manifestations of porphyry systems.

The Cedars Au-Ag prospect in the southern Shoshone Range is one of a small number of epithermal systems associated with the southward sweep of calc-alkaline magmatism (e.g., Round Mountain). However, this system formed 19 million years ago, after the main sweep of volcanism and during the very early onset of Basin and Range extensional faulting (Moore and O'Sullivan, 2005). 
Such studies of the attributes, magmatic affiliations, and relation to deformation of epithermal deposits in the Great Basin have been a foundation of regional syntheses (John and others, 2002, 2005; John, 2003, 2005). These studies comprised an important part of an invited paper for the 100th Anniversary Volume of Economic Geology (Simmons and others, 2005) that refined classifications and origins of epithermal gold-silver deposits around the world. It also provided a database on the geology and characteristics of the epithermal deposits in the Great Basin that are of international economic or scientific importance.

\section{Regional and district scale geologic and hydrologic models}

The relations between geologic data, models, interpretations and their inherent uncertainties were evaluated by Sweetkind and others (2002). A regional geologic model that encompasses the major mineral belts in northern Nevada (Carlin trend, Battle Mountain-Eureka trend, Getchell trend, Jerritt Canyon district, Alligator Ridge district, northern Nevada rift) is being constructed from a digital elevation model, the revised 1:250,000-scale geologic map of Nevada, deep drill holes, a series of geologic cross-sections, interpretations of geophysical data, and fossil/isotopic age information (Sweetkind and others, 2005a,b). A summary 3-D display of this information and a discussion of its relevance to the origin and evolutionary history of the mineral belts in northern Nevada is currently (2006) in preparation by D. Sweetkind and others.

To meet the needs of the project, the hydrologic modeling task had to develop new computer code that could handle high-permeability fault zones in 2-D simulations of crustal scale ground-water flow, heat, stable isotope, noble gases, and silica transport (Person and others, in press) and in 3-D simulations of fluid flow and heat transport. This task also used a "present is the key to the past" approach to calibrate the hydrologic parameters of rock units and structures. The district and deposit studies mentioned above show that convection of meteoric fluids in response to magmatism and/or extensional faulting can produce significant ore deposits. Hence, our initial modeling efforts only involve meteoric ground water and rocks. Two cross-sectional models were used to evaluate the importance of regional topography-driven fluid flow on present-day geothermal (Beowawe) and Miocene (Mule Canyon) hydrothermal systems located in the northern Nevada rift (Gao and others, 2003). These models suggest that fault dislocations are too numerous and rock permeabilities are too low for such regional flow systems to develop in Tertiary time. Rather, the modeling suggests that convection cells with restricted lateral and vertical extents are the norm.

Preliminary hydrogeologic models of the Dixie Valley and Beowawe geothermal areas, Miocene Mule Canyon low-sulfidation gold-silver system, and the Eocene Carlin gold trend evaluated the role of high-permeability fault zones. The results suggest that there are two endmember types of meteoric hydrothermal systems in the Great Basin (Hofstra, 2005b; Person and others, 2005). At one end are barren geothermal systems where convection is restricted to fault planes. The fluids interact little with wall rocks, have the smallest oxygen isotope shifts, and contain little gold. At the other end are Carlin systems where there was wholesale fluid convection through reduced sedimentary rocks enriched in gold. These mineralizing systems have the largest oxygen shifts and world-class endowments of gold. The Mule Canyon low-sulfidation system is intermediate in character. The 2- and 3-D geologic models for these systems are currently (2006) being refined and gridded (e.g., Tilden and others, 2005) for a final round of modeling. Some of these models will be used to evaluate the influence of magmatic heat and fluids. Manuscript(s) on the results of these hydrogeologic models are currently (2006) in preparation. 


\section{Metallogeny of the Great Basin Bibliography:}

\section{2-2006 publications by USGS personnel and collaborators}

Berger, B.B., Anderson, R.E., Phillips, J.D., and Tingley, J.V., 2005, Plate-boundary transverse deformation zones and their structural roles in localizing mineralization in the Virginia City, Goldfield, and Silver Star mining districts, Nevada, in Rhoden, H.N., Steininger, R.C., and Vikre, P.G., eds., Geological Society of Nevada Symposium 2005: Window to the World, Reno, Nevada, May 2005, p. 269-281.

Berger, V.I., and Theodore, T.G., 2005a, Implications of stratabound Carlin-type gold deposits in Paleozoic rocks of north-central Nevada; slide presentation: U. S. Geological Survey Open-File Report 2005-1156, 37 p.

Berger, V.I., and Theodore, T.G., 2005b, Implications of stratabound Carlin-type gold deposits in Paleozoic rocks of north-central Nevada, in Rhoden, H.N., Steininger, R.C., and Vikre, P.G., eds., Geological Society of Nevada Symposium 2005: Window to the World, Reno, Nevada, May 2005, p. 43-78.

Bliss, J.D., Moyle, P.R., and Long, K.R., eds., 2002, Contributions to Industrial-Minerals Research: U.S. Geological Survey Bulletin 2209, Version 1.0, URL http://pubs.usgs.gov/bul/b2209/.

Blodgett, R.B., Zhang, N., Hofstra, A.H., and Morrow, J.R., in press, Great Basin Paleontological Bibliography: U.S. Geological Survey Open-File Report, 171 manuscript pages.

Brueseke, M.E., Hart, W.K., Wallace, A.R., Heizler, M.T., and Fleck, R.J., 2003, Mid-Miocene volcanic field development in northern Nevada-New age constraints on the timing of Santa Rosa-Calico volcanism [abs.]: Geological Society of America, Abstracts with Programs, v. 35, no. 4 , p. 63.

Christiansen, W.D., Premo, W.R., Hofstra, A.H., Emsbo, P., and Lange, I.M., 2002, Stratabound SRHDG resource in Middle Proterozoic rocks of the Big Belt Mountains near York, Montana [abs.]: Geological Society of America, Abstracts with Programs, v. 34, no. 6, p. 143.

Chuang, F.C., McKee, E.H., Howard, K.A., 2003, Hydrogeologic factors that influence ground water movement in the desert southwest United States: U.S. Geological Survey Open-File Report 03-0294, 38 p., 21 sheets.

Church, S.E., Cox, D.P., Wooden, J.L., Tingley, J.V., and Vaughn, R.B., 2005, Base- and preciousmetal deposits in the Basin and Range of southern California and southern NevadaMetallogenic implication of lead isotope studies: Earth Science Reviews, v. 73, p. 323-346.

Clark, S.H.B., Poole, F.G., and Wang, Z., 2004, Comparison of some sediment-hosted, stratiform barite deposits in China, the United States, and India: Ore Geology Reviews, v. 24, nos.1-2, p. 85-101. 
Cline, J.S., Hofstra, A.H., Muntean, J., Tosdal, R.M., and Hickey, K.A., 2004, Characteristics and genesis of Carlin-type gold deposits, Nevada, USA: Special Publication, Centre for Ore Deposit and Exploration Studies (CODES), v. 5, p. 133-139.

Cline, J.S., Hofstra, A.H., Muntean, J.L., Tosdal, R.M., and Hickey, K.A., 2005, Carlin-type gold deposits in Nevada-Critical geologic characteristics and viable models: Economic Geology, 100th Anniversary Volume, p. 451-484.

Cline, J.S., Shields, J.S., Riciputi, L., Fayek, M., Copp, M., Muntean, T.L., and Hoftstra, A.H., 2003b, Trace element and isotope microanalyses support a deep ore fluid source at the Getchell Carlin-type gold deposit, northern Nevada [abs.]: Geological Society of America, Abstracts with Programs, v. 35 , no. 6, p. 358.

Cline, J.S., Stuart, F.M., Hofstra, A.H., Premo, W.R., Riciputi, L., Tosdal, R.M., and Tretbar, D.R., 2003a, Multiple sources of ore-fluid components at the Getchell Carlin-type gold deposit, Nevada, USA: 7th Biennial SGA-SEG Meeting, Athens, Greece, Aug. 24-28, 2003, 4 p.

Cline, J.S., Stuart, F.M., Hofstra, A.H., and Tretbar, D.R., 2002a, Helium and stable isotopic constraints on the source of ore fluid components at the Getchell Carlin-type gold deposit, northcentral Nevada, USA [abs.]: Eighth Biennial Pan-American Current Research on Fluid Inclusions, Halifax, Canada, Program with Abstracts, p. 23-24.

Cline, J.S., Stuart, F.M., Hofstra, A.H., Tretbar, D.R., Riciputi, L., and Premo, W.R., 2002b, He, $\mathrm{Nd}$, and stable isotope constraints on Carlin-type ore fluid components, Getchell, NV, USA [abs.]: Geological Society of America, Abstracts with Programs v. 34, no. 6, p. 141.

Coe, R.S., and Glen, J.M.G., 2004, The complexity of reversals, in Channell, J.E.T., Lowrie, W., and Meert, J., eds., Timescales of the internal geomagnetic field: American Geophysical Union, Geophysical Monograph.

Cook, H.E., 2005, Carbonate sequence stratigraphy: An exploration tool for sediment-hosted, disseminated gold deposits in the Great Basin, in Rhoden, H.N., Steininger, R.C., and Vikre, P.G., eds., Geological Society of Nevada Symposium 2005: Window to the World, Reno, Nevada, May 2005, p. 19-24.

Cook, H.E., 2006, Great Basin Paleozoic carbonate platform-Facies, facies transitions, depositional models, platform architecture, sequence stratigraphy, and predictive oil and gas reservoir and mineral host models: Nevada Petroleum Society Field Trip Guidebook, July 18-24.

Cook, H.E., and Corboy, J.J., 2004, Great Basin Paleozoic carbonate platform-Facies, facies transitions, depositional models, platform architecture, sequence stratigraphy, and predictive mineral host models: U.S. Geological Survey Open-File Report 2004-1078, 129 p., http://pubs.usgs.gov/of/2004/1078/

Crafford, E.J., 2005, Nevada tectonic history and ore deposits-Constraints provided by a new Nevada state digital geologic map [abs.], in Rhoden, H.N., Steininger, R.C., and Vikre, P.G., eds., Geological Society of Nevada Symposium 2005: Window to the World, Reno, Nevada, May 2005, p. 1308. 
Crafford, E., in press, Nevada State Digital Geologic Map: U.S. Geological Survey Open-File Report.

Crafford, A.E.J., and Grauch, V.J.S., 2002, Geologic and geophysical evidence for the influence of deep crustal structures on Paleozoic tectonics and the alignment of world class gold deposits, north-central Nevada, USA: Ore Geology Reviews, v. 21, p. 157-184.

Crafford, A.E.J., and Harris, A.G., 2005, New digital Conodont Alteration Index (CAI) maps of Nevada [abs.]: Geological Society of America, Abstracts with Programs, v. 37, no. 7, p. 379.

Crafford, E. and Harris, A.G., in press, Digital Conodont Database of Nevada: U.S. Geological Survey Open-File Report.

Cunningham, C.G., Austin, G.W., Naeser, C.W., Rye, R.O., Ballantyne, G.H., and Barker, C.E., 2002, Carlin-type gold deposits related to the Bingham Canyon, Utah, porphyry Cu deposit; thermal and isotopic constraints [abs.]: Geological Society of America, Abstracts with Programs v. 34 , no. 6, p. 143.

Cunningham, C.G., Austin, G.W., Naeser, C.W., Rye, R.O., Ballantyne, G.H., Stamm, R.G., and Barker, C.E., 2003, Formation of a paleothermal anomaly and disseminated gold deposits associated with the Bingham Canyon porphyry $\mathrm{Cu}-\mathrm{Au}-\mathrm{Mo}$ system, Utah: Economic Geology, v. 99, p. 789-806.

Cunningham, C.G., Austin, G.W., Naeser, C.W., Rye, R.O., Balantyne, G.H., Stamm, R.G., and Barker, C.E., 2005, Formation of a paleothermal anomaly and disseminated gold deposits associated with the Bingham Canyon porphyry $\mathrm{Cu}-\mathrm{Au}-\mathrm{Mo}$ system, Utah; Reply: Economic Geology, v. 100, p. 594-595.

Daliran, F., Hofstra, A., Walther, J., and Stuben, D., 2002, Agdarreh \& Zarshuran SRHDG Deposits, Takab Region, NW-Iran [abs.]: Geological Society of America Abstracts with Programs, v. 34, no. 6, p. 141.

Day, H.W., Blake, M. C., Ernst, W. G., Hacker, B. R., Howard, K., Jacobson, C., Springer, R. K., Todd, V., and Wentworth, C., 2003, A preliminary metamorphic map of California [abs.]: Geological Society of America, Abstracts with Programs, v. 35, no. 6, p. 96.

Diehl, S.F., Hofstra, A.H., Emsbo, P., Koenig, A., Vikre, P., and Lufkin, J., 2005a, Distribution of hydrothermal zebra dolomite and its relation to base and precious metal deposits in the Great Basin, in Rhoden, H.N., Steininger, R.C., and Vikre, P.G., eds., Geological Society of Nevada Symposium 2005: Window to the World, Reno, Nevada, May 2005, p. 187-208.

Diehl, S.F., Hofstra, A.H., Koenig, A., Lufkin, J., Emsbo, P., and Vikre, P., 2005b, Paleozoic tectonics, brine migration, and formation of hydrothermal zebra dolomite, sedex, and MVT deposits along the carbonate platform in the Great Basin [abs.]: Geological Society of America, Abstracts with Programs, v. 37, no. 7, p. 379. 
du Bray, E.A., Ressel, M.W., and Barnes, C.G., in press, Geochemical database for intrusive rocks of northeast Nevada: U.S. Geological Survey Data Series Report.

du Bray, E.A., and Nash, J.T., 2005, A new whole-rock major and trace element geochemical database for intrusive rocks of northern Nevada-Implications for petrogenesis and metallogeny [abs.]: Geological Society of America, Abstracts with Programs, v. 37, no. 7, p. 379.

Emsbo, P., 2004, Genetic links among syngenetic metal accumulations in sedimentary basins; giant sediment-hosted metal deposits to metalliferous black shales: Geological Society of America, Abstracts with Programs, v. 36, no. 5, p. 199.

Emsbo, P., Griffin, G.L., and Hofstra, A.H., 2002, Geology, geochemistry, and genesis of SEDEX $\mathrm{Au}$ ores on the Carlin Trend, Nevada [abs.]: Geological Society of America, Abstracts with Programs v. 34, no. 6, p. 140.

Emsbo, P., Groves, D.I., Hofstra, A.H., and Bierlein, F.P., 2006, The giant Carlin gold provinceA protracted interplay of orogenic, basinal, and hydrothermal processes above a lithospheric boundary: Mineralium Deposita, v. 41, p. 517-525.

Emsbo, P., and Koenig, 2005, Discovery and significance of gold-rich bitumen in the Rodeo deposit, northern Carlin trend, Nevada [abs.]: Geochimica et Cosmochimica Acta, v. 69, p. 123.

Emsbo, P., and Morrow, J. R., 2005, Links between Devonian basin architecture and gold mineralization, north-central Nevada-An undervalued tectonic control? [abs.]: Geological Society of America, Abstracts with Programs, v. 37, no. 7, p. 418.

Emsbo, P., Zhang, X-C., Hofstra, A.H., Hu, R-Z., Johnson, C.A., Su, W-C., Pi, D-H., Koenig, A., and Grauch, R., 2005, Lower Cambrian metallogenesis of south China-Interplay between diverse basinal hydrothermal fluids and marine chemistry, in Mao, J. and Bierlein, F.P., eds., Mineral Deposit Research: Meeting the Global Challenge, Proceedings of the 8th Biennial SGA Meeting, Beijing, China, 18-21 August 2005, p. 115-118.

Evans, J.G., 2003, Preliminary geologic map of the Unity Reservoir quadrangle, Baker County, Oregon: U.S. Geological Survey Miscellaneous Field Studies Map, scale 1:24,000.

Evans, J.G., Griscom, A., Halvorson, P.F., and Cummings, M.L., 2004, Tracking the western margin of the North American Craton beneath southeastern Oregon-A multidisciplinary approach: Idaho Geological Survey Bulletin 30, p. 35-58.

Gao, Yongli, Person, M. A., Dahlstrom, D., Hofstra, A., Sweetkind, D., Howard, K., John, D., Prudic, D., and Wallace, A., 2003, The role of faults in the plumbing of the Great Basin geothermal systems and gold mineralization [abs.]: Geological Society of America, Abstracts with Programs, v. 35, no. 6, p. 617.

Glen, J.M.G., and Ponce, D.A , 2002, Large-scale fractures related to inception of the Yellowstone Hotspot: Geology, v. 30, no.7, p. 647-650. 
Glen, J.M.G., McKee, E. H., Ludington, S., Ponce, D.A., Hildenbrand, T.G., and Hopkins, M.J., 2004a, Geophysical terranes of the Great Basin and parts of surrounding provinces: U.S. Geological Survey Open-File Report 2004-1008, 303 p.

Glen, J.M.G., Ponce, D.A., Nomade, S., and John, D.A., 2003, Dike emplacement and the birth of the Yellowstone hotspot, western USA [abs.]: EGS-AGU-EUG joint assembly, Nice, France, April 2003.

Glen, J.M.G., Ponce, D.A., and Sepulveda, E., 2004b, Yellowstone hotspot melting and its relation to pre-existing crustal structures and Great Basin extension: Eos, Transactions, American Geophysical Union, 85(47), Fall Meeting Supplement, Abstract V51B-0555.

Goldfarb, Richard J., Hart, Craig, J.R., Mao, J., and Hofstra, A.H., 2004, Gold in China-The present understanding of emerging world-class resources [abs.]: Geological Society of Australia Abstracts, v. 73, p. 82.

Granitto, M., Yager, D., and Hofstra, A.H., 2005, Geochemical data for the Great Basin-A subset of the USGS new National Geochemical Database [abs.]: Geological Society of America, Abstracts with Programs, v. 37, no. 7, p. 380.

Grauch, V.J.S., Rodriguez, B.D., Bankey, V., and Wooden, J.L., 2003, Evidence for a Battle Mountain-Eureka crustal fault zone, north-central Nevada, and its relation to NeoproterozoicEarly Paleozoic continental breakup: Journal of Geophysical Research, v. 108, no. B3, 18 p.

Hofstra, A.H., 2002a, Distinguishing characteristics and models for Carlin-type gold deposits, in Thorman, C., ed., SEG Carlin-type deposits of northern Nevada and their regional setting field trip, April 17-21, 2002, Guidebook and CD ROM.

Hofstra, A.H., 2002b, Diverse origins of sedimentary rock-hosted disseminated gold deposits worldwide-Overview [abs.]: Geological Society of America, Abstracts with Programs v. 34, no. 6, p. 140.

Hofstra, A.H., 2004, Diverse origins of sedimentary rock-hosted disseminated gold deposits-A global perspective, in Irish Association for Economic Geology (IAEG) Weekend Course on Sediment-Hosted Gold Deposits, May 15-16, Bundoran, Ireland, 5 p.

Hofstra, A.H., 2005a, Carlin-type gold deposits, in Scott, S., Mo, X., and Yang, K., organizers, SGA Short Course SHC-3, Metallogeny: Current theory and exploration models, associated with the 8th Biennial SGA Meeting, Beijing, China, 15-17 August, 2005, p. 79-109.

Hofstra, A.H., 2005b, Great Basin metallogeny-Interplay of tectonic events, basement faults, permeability, diverse fluids, rock buffers, \& physicochemical traps [abs.]: Geological Society of America, Abstracts with Programs, v. 37, no. 7, p. 418.

Hofstra, A.H., and Emsbo, P., 2005, Source of salt in hydrothermal fluids based on Na-Cl-Br of fluid inclusions [abs.]: Geochimica et Cosmochmica Acta, v. 69, 1 p. 
Hofstra, A.H., Emsbo, P., Hu, R., Zhang, X., and Su, W., 2005a, Origin and potential for significant Carlin-like gold deposits in China-Synthesis of new observations and data with published information [abs.]: 2005 SME Annual Meeting and Exhibition, Feb. 28-Mar. 2, Salt Lake City, Utah, Technical Program, p. 50.

Hofstra, A.H., Emsbo, P., Hu, R., Zhang, X., Su, W., Nutt, C.J., and Fifarek, R.H., 2005b, Diverse origins of sedimentary rock-hosted disseminated gold deposits in the Great Basin and southern China [abs.], in Rhoden, H.N., Steininger, R.C., and Vikre, P.G., eds., Geological Society of Nevada Symposium 2005: Window to the World, Reno, Nevada, May 2005, p. 1315-1316.

Hofstra, A.H., John, D.A., and Theodore, T.G., 2003, A special issue devoted to gold deposits in northern Nevada-Part 2. Carlin-type deposits: Economic Geology, v. 98, p. 1063-1067.

Hofstra, A.H., Zhang, X-C, Emsbo, P., Hu, R-H, Su,W-C, Christiansen, W.D., Fu, S-H, and Theodorakos, P., 2005c, Source of ore fluids in Carlin-type gold deposits in the Dian-Qian-Gui area and West Qinling belt, P.R. China-Implications for genetic models, in Mao, J. and Bierlein, F.P., eds., Mineral Deposit Research: Meeting the Global Challenge, Proceedings of the 8th Biennial SGA Meeting, Beijing, China, 18-21 August 2005, p. 533-536.

Hook, S.J., Dmochowski, J.E., Howard, K.A., Rowan, L.C., Karlstrom, K.E., and Stock, J.M., 2005, Variations in weight percent silica measured from remotely acquired multispectral thermal infrared data-Examples from the Hiller Mountains, Nevada, USA and Tres Virgenes-La Reforma, Baja California Sur, Mexico: Remote Sensing of Environment.

Howard, K.A., 2002, Ruby Mountains core complex as a guide to Eocene deep crustal structure in the Elko-Carlin region, Nevada [abs.]: Geological Society of America, Abstracts with Programs, v. 34 , no. 6, p. 83 .

Howard, K.A., 2003, Crustal structure in the Elko-Carlin region, Nevada, during Eocene gold mineralization-Ruby-East Humboldt metamorphic core complex as a guide to the deep crust: Economic Geology, v. 98, no. 2, p. 249-268.

Howard, K.A., 2005, The upper crust laid on its side-Tectonic implications of steeply tilted crustal slabs for extension in the Basin and Range [abs.]: Geological Society of America, Abstracts with Programs, v. 37, no. 7, p. 419.

Howard, K.A., Barnes, C.B., Snoke, A.W., Wright, J.E., and Lee, S., 2004a, Style of intrusion of crustal melts into middle crust in the Cretaceous back-arc-Ruby Mountains core complex, Nevada [abs.]: Geological Society of America, Abstracts with Programs, v. 36, no. 4, p. 71.

Howard, K.A., Barnes, C.G., Snoke, A.W., Wright, J.E., and Lee, S.., 2004b, Incremental assembly of a batholith from crustal melts on the continental fringe of a Cretaceous arc-Ruby Mountains, Nevada, U.S.A [abs.]: Pucon, Chile, International Association of Volcanology and Chemistry of the Earth's Interior (IAVCEI), Abstracts for session 9c.

Howard, K.A., Jachens, R.C., Chuang, F.C., and McKee, E.H., in press, Geohydrologic factors that influence the movement of ground-water in the Great Basin-Preliminary report: U.S. Geological Survey Open-File Report, 80 manuscript p. 
Howard, K.A. and MacCready, T., 2004, Geologic map of the Verdi Peak Quadrangle, Elko County, Nevada: Nevada Bureau of Mines and Geology Map 147, scale 1:24,000, also available at.http://www.nbmg.unr.edu/dox/m147text.pdf and http://www.nbmg.unr.edu/dox/m147plate.pdf.

Howard, K.A., and Nutt, C.J., 2005, Extension-related folds in Eocene rocks, northeastern Nevada [abs.], in Rhoden, H.N., Steininger, R.C., and Vikre, P.G., eds., Geological Society of Nevada Symposium 2005: Window to the World, Reno, Nevada, May 2005, p. 1316.

Hudson, D.M., John, D.A., and Fleck, R.J., 2005, Geologic setting, geochemistry, and geochronology of epithermal gold-silver deposits in the Seven Troughs district, northwest Nevada [abs.]: Geological Society of America, Abstracts with Programs, v. 37, no. 7, p. 380.

Hudson, D.M., John, D.A., and Fleck, R.J., 2006, Geology, geochemistry, and geochronology of epithermal gold-silver deposits in the Seven Troughs district, Pershing County, Nevada: Geological Society of Nevada Special Publication 42, p. 110-126.

Jarboe, N., Coe, R.S., Glen, J.M.G., and Renne, P.R., 2003, A study of mid-Miocene Yellowstone hotspot volcanics and the search for the Steens Mountain Reversal [abs.]: Eos, Transactions, American Geophysical Union, Fall Meeting Supplement, 84(46), Abstract GP11C-0276.

Jarboe, N., Coe, R.S., Glen, J.M.G., and Renne, P.R., 2004, Investigating the timing and extent of early Yellowstone hotspot volcanism while expanding the Steens Mountain Magnetic reversal record [abs.]: Eos, Transactions, American Geophysical Union, Fall Meeting Supplement, 85(47), Abstract GP11D-0866.

John, D.A., in press, Geology and mining history of the Park City mining district, Utah, in Mining Camps of Utah: Utah Geological Association Guidebook, 41 manuscript p., 4 tables, 9 figs., 4 photographs (editor deceased Sept. 2004_publication delayed).

John, D.A., 2003, New perspectives on the origin and distribution of Cenozoic epithermal goldsilver deposits in the northern Great Basin and surrounding environs [abs.]: Spokane, Washington, Northwest Mining Association Abstract Book, Dec. 2-6, 2003, p. 17-18.

John, D.A., 2005, New perspectives on the origin and distribution of Cenozoic epithermal goldsilver deposits in the northwestern United States [abs.]: Atlantic Geology (Geological Association of Canada sectional meeting, Feb. 2005, St. Johns, Newfoundland).

John, D.A., Breit, G.N., Rye, R.O., Sisson, T.W., and Vallance, J.W., 2003a, Hypogene hydrothermal alteration of Quaternary volcanic rocks from Mount Rainier, Washington: Geological Society of America, Abstracts with Programs, v. 35, no. 6, p. 553.

John, D.A., and Henry, C.D., 2005, Multiple units of the Caetano Tuff, northern Nevada-Caldera source and preliminary geochronology and geochemistry [abs.]: Geological Society of America, Abstracts with Programs, v. 37, no. 7, p. 379. 
John, D.A., and Hofstra, A.H., 2002, Hydrothermal alteration and stable isotope constraints on formation of the Mule Canyon low-sulfidation Au-Ag deposit, north-central Nevada [abs]: Geological Society of America, Abstracts with Programs, v. 34, no. 5, p. A-15.

John, D.A., Hofstra, A.H., and Theodore, T.G., 2003b, Preface to special issues devoted to gold deposits in northern Nevada-Part 1, regional studies and epithermal deposits: Economic Geology, v. 98, no. 2, p. 225-234.

John, D., and Muntean, J., 2006, Summary of characteristics of Tertiary metallic mineral deposits in the Lovelock area, northwestern Nevada: Geological Society of Nevada Special Publication 42, p. 60-69.

John, D.A., Wallace, A.R., and Hofstra, A.H., 2002, Middle Miocene epithermal Au-Ag deposits related to continental tholeiitic basalt magmatism, northern Great Basin, western USA [abs]: Geological Society of America, Abstracts with Programs, v. 34, no. 6, p. 185.

John, D.A., Wallace, A.R., and Coolbaugh, M.F., 2005, Epithermal gold-silver deposits associated with Neogene bimodal magmatism in the northern Great Basin [abs.]: Geological Society of America, Abstracts with Programs, v. 37, no. 7, p. 419.

John, D.A., and Wrucke, C.T., 2003, Geologic map of the Mule Canyon quadrangle, Lander County, Nevada: Nevada Bureau of Mines and Geology Map 144, scale 1:24,000, 16 p.

Johnson, C.A., and Emsbo, P., 2004, Sulfur and oxygen isotopes of barite deposits in sedimentary basins-Implications for barite genesis, massive sulfide genesis, and sulfur redox reactions [abs.]: Geological Society of America, Abstracts with Programs, v. 36, no. 5, p. 200-201.

Ketner, K.B., Crafford, A.E.J., Harris, A.G., Repetski, J.E., and Wardlaw, B.R., 2005, Late Devonian to Mississippian arkosic rock derived from a granitic terrane in northwestern Nevada adds a new dimension to the Antler orogeny, in Rhoden, H.N., Steininger, R.C., and Vikre, P.G., eds., Geological Society of Nevada Symposium 2005: Window to the World, Reno, Nevada, May 2005, p. 135-146.

Koski, R.A., and Hein, J.R., 2003, Stratiform barite deposits in the Roberts Mountains Allochthon, Nevada-A review of potential analogs in modern sea-floor environments: U.S. Geological Survey Bulletin B 2209-H, 17 p.

Landis, G.P., and Rye, R.O., 2005, Characterization of gas chemistry and noble-gas isotope ratios of inclusion fluids in magmatic-hydrothermal and magmatic-steam alunite: Chemical Geology, v. 215 , nos. 1-4, p. 155-184.

Leavitt, E., Spell, T.L., Wallace, A.R., Goldstrand, P., and Arehart, G.B., 2003, Volcano-tectonic setting of the Midas epithermal vein deposit, Elko County, Nevada [abs.]: Geological Society of America, Abstracts with Programs, v. 35, no. 4, p. 61.

Lee, S.-Y., Barnes, C.G., Snoke, A.W., Howard, K.A., and Frost, C.D., 2003, Petrogenesis of Mesozoic peraluminous granites in the Lamoille Canyon area, Ruby Mountains, Nevada, USA: Journal of Petrology, v. 44, p. 713-732. 
Ludington, S., and John, D., 2002, Magmatic and metallogenic specialization of volcanic rocks related to epithermal gold mineralization, Great Basin, USA [abs], in Interaction between mafic and felsic melts in orogenic suites-dynamics of processes, nature of end-members, effects: Prefield Meeting Workshop, Abstract Volume, Eurogranites 2002, p. 37, URL http://www.unipg.it/ petropg/workshop.htm.

Ludington, S., Folger, H., Kotlyar, B.B., Mossotti, V.G., Coombs, M.J., and Hildenbrand, T.G., 2006, Regional surficial geochemistry of the northern Great Basin: Economic Geology, v. 101, no. 1, p. 33-57.

Ludington, S., Moring, B.C., Miller, R.J., Flynn, K., Hopkins, M.J., Stone, P., Bedford, D.R., and Haxel, G.A., 2005, Preliminary integrated geologic map databases for the United States western states; California, Nevada, Arizona, and Washington, version 1.0: U. S. Geological Survey OpenFile Report 2005-1305.

McCabe, J., Hackett, L., Sweetkind, D., and Poole, F.G., 2005, Application of digital stratigraphic data from measured sections in the northern Great Basin [abs.]: Geological Society of America, Abstracts with Programs, v. 37, no. 7, p. 378-379.

McGibbon, D.H., and Theodore, T.G., 2002, Magmatic affiliations for enigmatic gold deposits in the northern Battle Mountain mining district, Nevada [abs.]: Geological Society of America, Abstracts with Programs, v. 34, no. 6, p. 142.

Moore, T.E., Murchey, B.L., Moring, B.C., Harris, A.G., Blodgett, R.B., O'Sullivan, P.G., and Fleck, R.J., in press, Geology of the Cedars Quadrangle, Lander County, Nevada: Nevada Bureau of Mines and Geology Map, 42 manuscript p., 1 sheet, scale 1:24,000.

Moore, T.E., and O'Sullivan, P.B., 2005, Miocene gold mineralization and exhumation of the southern Shoshone Range, north-central Nevada, in Rhoden, H.N., Steininger, R.C., and Vikre, P.G., eds., Geological Society of Nevada Symposium 2005: Window to the World, Reno, Nevada, May 2005, p.103-124.

Morgan, L.A., Pierce, K.L., and McIntosh, W.C., 2004, Patterns of volcanic and tectonic events in the wake of the Yellowstone Hot Spot: Geological Society of America, Abstracts with Programs, v. 36 , no. 5 , p. 546 .

Nash, J.T., 2004, Hydrogeochemcial studies of historical mining areas in the Humboldt River Basin and adjacent areas, northern Nevada: U.S. Geological Survey Scientific Investigations Report 2004-5236, CD-ROM.

Nazarova, K., and Glen, J.M.G., 2004, Integration of NASA/GSFC and USGS Rock Magnetic Databases, Eos, Transactions, American Geophysical Union, Spring Meeting Supplement, 85(17), Abstract GP21A-04.

Nutt, C.J., 2002, Paleogene deformation, sedimentation, and magmatism in northeast Nevada, in Thorman, C., ed., SEG Carlin-type deposits of northern Nevada and their regional setting, field trip, April 17-21, 2002, Guidebook and CD ROM. 
Nutt, C.J., and Hart, K.S., 2004, Geologic map of the Big Bald Mountain Quadrangle and part of the Tognini Spring Quadrangle, White Pine County, Nevada: Nevada Bureau of Mines and Geology Map 145, 8 p., 1 sheet.

Nutt, C.J., and Hofstra, A.H., 2002, Jurassic intrusion-related and Eocene Carlin-type gold mineralization in the Bald Mountain-Alligator Ridge area, east-central Nevada [abs.]: Geological Society of America, Abstracts with Programs v. 34, no. 6, p. 142.

Nutt, C.J., and Hofstra, A.H., in press, Bald Mountain, Nevada-A reduced intrusion-related gold district: Economic Geology, 42 manuscript p.

Nutt, C.J., and Howard, K.A., 2003, Eocene basins in northeastern Great Basin, Utah and Nevada, and their significance [abs.]: Geological Society of America, Abstracts with Programs, v. 35, no. 6, p. 26.

Nutt, C.J., and Ludington, S., 2003, Intrusive rock database for the digital geologic map of Utah: U.S. Geological Survey Open-File Report 03-0486, 41 p.

Nutt, C.J., and Thorman, C.H., 2005, Role of low-angle to bedding-parallel faults in localizing Carlin-type gold, northern Nevada [abs.]: Geological Society of America, Abstracts with Programs, v. 37, no. 7, p. 418.

Percival, T.J., and Hofstra, A.H., 2002a, Alsar district, Macedonia-Pliocene SRHDG mineralization associated with shoshonitic magmatism [abs.]: Geological Society of America, Abstracts with Programs v. 34, no. 6, p. 142.

Percival, T.J., and Hofstra, A.H., 2002b, Bau, Malaysia-SRHDG deposit associated with Miocene magmatism [abs.]: Geological Society of America, Abstracts with Programs v. 34, no. 6, p. 142.

Person, M., Gao, Y., Hofstra, A., Sweetkind, D., and Prudic, D., 2005, Numerical models of fluid flow in Great Basin geothermal systems and Tertiary hydrothermal gold deposits-Role of high permeability fault zones [abs.], in Rhoden, H.N., Steininger, R.C., and Vikre, P.G., eds., Geological Society of Nevada Symposium 2005: Window to the World, Reno, Nevada, May 2005, p. 1324-1325.

Person, M., Zhang, L., Wang, P., Gao,Y., and Hofstra, A., in press, A new parallel multicomponent, finite element model for simulating crustal-scale groundwater flow, heat, isotope, noble gas, and silica transport [abs.]: Geological Society of America, Abstracts with Programs, 1 p.

Pierce, K.L., Morgan, L.A., and Saltus, R.W., 2004, Yellowstone plume head-Postulated tectonic relations to the Vancouver Slab, continental boundaries, and climate: Idaho Geological Survey Bulletin 30, p. 1-34.

Plenier, G., and Glen, J.M.G., 2004, Complex magnetic fabrics in igneous rocks [abs.]: Eos, Transactions, American Geophysical Union, Fall Meeting Supplement, 85(47), Abstract GP23B06. 
Pluhar, C.J., Coe, R.S., Nomade, S., Glen, J.M.G., and Lewis, J.C., 2003a, Kinematics of the Coso Range Block Rotation from Paleomagnetism, XRF Geochemistry and Ar/Ar Geochronology of Pliocene Lavas [abs.]: U.S. Navy Geothermal Program, Office conference.

Pluhar, C.J., Nomade, S., Glen, J.M.G., and Coe, R.S., 2003b, Jaramillo, Cobb Mtn., or Punaruu?Re-examination of "Cobb Mtn. Event" lavas at the Coso volcanic field, CA [abs.]: Eos, Transactions, American Geophysical Union, Fall Meeting Supplement, 84(46), Abstract GP31D0774.

Pluhar, C.J., Nomade, S., Glen, J.M.G., Coe, R.S., and Renne, P.R., 2004, Magnetostratigraphy, geochronology and geochemical evolution of the Pliocene Coso volcanic field, CA and contemporaneity with Sierra Nevada delamination [abs.]: Geological Society of America, Abstracts with Programs, v. 36, no. 5, p. 430-431.

Ponce, D.A., and Glen, J.M.G., 2005, A prominent basement feature in north-central Nevada and its tectonic implications [abs.]: Geological Society of America, Abstracts with Programs, v. 37, no. 7, p. 378 .

Potter, C.J., Sweetkind, D.S., Dickerson, R.P., and Killgore, M.L., 2002, Hydrostructural maps of the Death Valley region flow system, Nevada and California: U.S. Geological Survey Miscellaneous Field Studies Map MF-2372, 12 p., 2 sheets.

Premo, W.R., Howard, K.A., and Castenieras, P., 2005, New SHRIMP U-Pb zircon ages and Nd isotopic signatures for plutonism in the Northern Ruby-East Humboldt Ranges of NE NevadaImplications for the timing of Tertiary core complex formation [abs.]: Geological Society of America, Abstracts with Programs, v. 37, no. 7, p. 359.

Racheboeuf, P.R., Moore, T.E., and Blodgett, R.B., 2004, A new Permian chonetoidean brachiopod from Nevada (United States) and stratigraphic implications for the Antler overlap assemblage: GEOBIOS, v. 37, p. 382-394.

Ramelli, A.R., Yount, J.C., John, D.A., and Garside, L.J., 2003, Preliminary geologic map of the Minden quadrangle, Douglas County, Nevada and Alpine County, California: Nevada Bureau of Mines and Geology Open-File Report 03-13, scale 1:24,000.

Rodriguez, B.D., Grauch, V.J.S., and Williams, J.M., 2005, Preliminary deep crustal investigations to locate the Archean/Proterozoic suture zone in the Great Basin, using magnetotellurics, in Rhoden, H.N., Steininger, R.C., and Vikre, P.G., eds., Geological Society of Nevada Symposium 2005: Window to the World, Reno, Nevada, May 2005, p. 13-18.

Rodriguez, B.D., and Williams, J.M., 2002, Resistivity structure across the Humboldt River Basin, north-central Nevada: U.S. Geological Survey Open-File Report 02-39, 114 p.

Rodriguez, B.D., and Williams, J.M., 2005, Major crustal fault zones trend obliquely to mineral belts in the Great Basin [abs.]: Geological Society of America, Abstracts with Programs, v. 37, no. 7, p. 418. 
Rye, R.O., 2005, A review of the stable-isotope geochemistry of sulfate minerals in selected igneous environments and related hydrothermal systems: Chemical Geology, v. 215, nos.1-4, p. 5-36.

Rytuba, J.J., John, D.A., Foster, A., Ludington, S.D., and Kotylar, B., 2003, Hydrothermal enrichment of gallium in zones of advanced argillic alteration; examples from the Paradise Peak and McDermitt ore deposits, Nevada: U.S. Geological Survey Bulletin 2209-C, 35 p.

Rytuba, J.J., John, D.A., and McKee, E.H., 2004, The track of the Yellowstone Hot Spot-What is the geology telling us about the processes below? [abs.]: Geological Society of America, Abstracts with Programs, v. 36, no. 4, p. 94-95.

Samal, A.R., Fifarek, R. H., and Thomason, R.E., 2005, Steam-heated alteration at the Florida Canyon epithermal gold deposit, Nevada-Assemblages, timing, and possible fluid sources [abs.]: Geological Society of America, Abstracts with Programs, v. 37, no. 7, p. 420.

Scott, R.B., and Harding, A.E., in press, Geologic map of the Vigo NE quadrangle, Lincoln County, Nevada: Scientific Investigations Map 2892, scale 1:24,000.

Simmons, S.F., White, N.C., and John, D.A., 2005, Epithermal precious and base metal deposits, in Hedenquist, J.W., Thompson, J.F.H., Goldfarb, R.J., and Richards, J.P., eds., Economic Geology, One Hundredth Anniversary Volume, p. 485-522.

Snoke, A.W., Barnes, C.B., Howard, K.A., Wright, J.E., and Copeland, P., 2004, Late Eocene and Oligocene intrusions in the Ruby-East Humboldt core complex, Nevada-Magmatic processes in the middle crust in relation to tectonic extension [abs.]: Geological Society of America, Abstracts with Programs, v. 36, no. 4, p. 71.

Sweetkind, D.S., Dickerson, R.P., Blakely, R.J., and Denning, P.D., 2001, Interpretive geologic cross sections for the Death Valley regional flow system and surrounding areas, Nevada and California: U.S. Geological Survey Miscellaneous Field Studies Map MF-2370, 35 p., 3 sheets.

Sweetkind, D.S., Faunt, C.C., and Phelps, G., 2002, Evaluation and quantification of uncertainty inherent in geologic data, interpretations and conceptual models [abs.]: EOS, Transactions, American Geophysical Union, v. 83, p. F497.

Sweetkind, D.S., Wallace, A.R., Nutt, C.J., John, D.A., Howard, K.A., Person, M.A., Ponce, D.A., Glen, J.M.G., and Evans, J.G., 2005b, Tectonic reconstructions based on regional cross sections to increase understanding of metallogeny and fluid flow in the northern Great Basin [abs.]: Geological Society of America, Abstracts with Programs, v. 37, no. 7, p. 379.

Sweetkind, D.S., Wallace, A.R., Nutt, C.J., John, D.A., Howard, K.A., Ponce, D.A., Glen, J.M.G., Moore, T.E., and Hofstra, A.H., 2005a, Reconstructing northern Great Basin geologic and mineralizing events using regional cross sections [abs.], in Rhoden, H.N., Steininger, R.C., and Vikre, P.G., eds., Geological Society of Nevada Symposium 2005: Window to the World, Reno, Nevada, May 2005, p. 1329. 
Theodore, T.G., Berger, V.I., Singer, D.A. Harris, A.G., and Stevens, C.H., 2004, Synthrusting deposition of the Pennsylvanian and Permian Strathearn Formation, northern Carlin trend, Nevada: Sedimentary Geology, v. 165, p. 1-28.

Theodore, T.G., and Kotlyar, B.B., 2002, Geologic setting of the Battle Mountain-Eureka mineral belt, in Thorman, C., ed., SEG Carlin-type deposits of northern Nevada and their regional setting field trip, April 17-21, 2002, Guidebook and CD ROM.

Theodore, T.G., Moring, B.C., Harris, A.G., Armstrong, A.K., and Finney, S.C., 2003, Geologic map of the Beaver Peak Quadrangle, Elko and Eureka Counties, Nevada: Nevada Bureau of Mines and Geology Map 143, scale 1:24,000, 14 p., 1 sheet.

Thorman, C.H., 2002, Regional stratigraphic and structural setting of the Carlin trend region, Nevada-An overview, in Thorman, C., ed., SEG Carlin-type deposits of northern Nevada and their regional setting field trip, April 17-21, 2002, Guidebook and CD ROM.

Thorman, C.H., Brooks, W.E., Ketner, K.B., and Dubiel, R.F., 2003, Preliminary geologic map of the Oxley Peak area, Elko County, Nevada: Nevada Bureau of Mines and Geology Open-File Report 2003-4, scale 1:24,000.

Thorman, C.H., and Peterson, F., 2003, The Middle Jurassic Elko Orogeny; a major tectonic event in Nevada-Utah [abs.]: American Association of Petroleum Geologists Annual Meeting Expanded Abstracts, v. 12, p. 169.

Tilden, J.E., Ponce, D.A., Glen, J.M.G., John, D.A., and Person, M.A., 2005, Three-dimensional geologic model of the Beowawe geothermal area, north-central Nevada [abs.]: Geological Society of America, Abstracts with Programs, v. 37, no. 7, p. 380.

Turner, S.J., Garwin, S.A., and Hofstra, A.H., 2002, Mesel SRHDG deposit and low-sulfidation gold veins in the Ratatotok district, North Sulawesi, Indonesia [abs.]: Geological Society of America, Abstracts with Programs v. 34, no. 6, p. 141.

Vikre, P.G., in press, Sinter-vein correlations at Buckskin Mountain, National district, Humboldt County, Nevada: Economic Geology, 48 manuscript p.

Vikre, P.G., Fleck, R.J., and Rye, R.O., 2005a, Ages and geochemistry of magmatic hydrothermal alunites in the Goldfield District, Esmeralda Co., Nevada: U.S. Geological Survey Open-File Report 2005-1258, 1 sheet.

Vikre, P.G., Fleck, R.J., and Rye, R.O., 2005b, Ages and geochemistry of magmatic hydrothermal alunites in the Goldfield District, Esmeralda Co., Nevada [abs.], in Rhoden, H.N., Steininger, R.C., and Vikre, P.G., eds., Geological Society of Nevada Symposium 2005: Window to the World, Reno, Nevada, May 2005, p. 1330-1331.

Vikre, P., Garside, L.J., Castor, S.B., Henry, C.D., Hudson, D.M., and McIntosh, W.C., 2003, Multiple episodes of magmatism, quartz-alunite alteration, and adularia-sericite precious metal mineralization, western Virginia Range, Nevada [abs.]: Geological Society of America, Abstracts with Programs, v. 35, no. 6, p. 401. 
Wallace, A.R., 2002, Late Cenozoic evolution of the Great Basin-Applications to precious-metal, diatomite, and geothermal resources [abs.]: Northwest Mining Association Annual Meeting, Abstract Book, p. 3-4.

Wallace, A.R., 2003a, Geologic map of the Willow Creek Reservoir quadrangle, Elko County, Nevada: Nevada Bureau of Mines and Geology Map 135, scale 1:24,000, 16 p.

Wallace, A.R., 2003b, Geologic map of the Willow Creek Reservoir SE Quadrangle, Elko, Eureka, and Lander Counties, Nevada: Nevada Bureau of Mines and Geology Map 136, 1:24,000, 15 p.

Wallace, A.R., 2003c, Geology of the Ivanhoe Hg-Au district, northern Nevada-Influence of Miocene volcanism, lakes, and active faulting on epithermal mineralization: Economic Geology, v. 98, no. 2, p. 409-424.

Wallace, A.R., 2003d, Regional geologic setting of late Cenozoic lacustrine diatomite deposits, Great Basin and surrounding region-Overview and plans for investigation, in Bliss, J.D., Moyle, P.D., and Long, K.R., eds., Contributions to Industrial-Minerals Research, Chapter B: U.S. Geological Survey Bulletin 2209, 15 p.

Wallace, A.R., 2004, Processes related to the formation of Neogene lacustrine diatom-rich sediments and diatomite deposits, Great Basin region, in Castor, S.B., Papke, K.G., and Meeuwig, R.O., eds., Betting on Industrial Minerals-Proceedings of the 39th Forum on the Geology of Industrial Minerals: Nevada Bureau of Mines and Geology Special Publication 33, p. 229-242.

Wallace, A.R., 2005a, Late Cenozoic landscape evolution in northeastern Nevada and its predictive implications for mineral deposits and ground water [abs.]: Geological Society of America, Abstracts with Programs, v. 37, no. 7, p. 419.

Wallace, A.R., 2005b, Sedimentation, faulting, and erosion in the Carlin basin, northeastern Nevada, and implications for mineral exploration and ground water resources, in Rhoden, H.N., Steininger, R.C., and Vikre, P.G., eds., Geological Society of Nevada Symposium 2005: Window to the World, Reno, Nevada, May 2005, p. 147-160.

Wallace, A.R., Fleck, R.J., and Theodore, T.G., 2004a, New studies on the middle Miocene Humboldt Formation, northeastern Nevada [abs.]: Geological Society of America, Abstracts with Programs, v. 36, no. 4, p. 7.

Wallace, A.R., Ludington, S., Mihalasky, M.J., Peters, S.G., Theodore, T.G., Ponce, D.A., John, D.A., Berger, B.R., Zientek, M.L., Sidder, G.B., and Zierenberg, R.A., 2004b, Assessment of metallic resources in the Humboldt River basin, northern Nevada, with a section on Platinumgroup-elements (PGE) potential of the Humboldt mafic complex: U.S. Geological Survey Bulletin 2216, 1 disc.

Wallace, A.R., Perkins, M.E., and Fleck, R.J., in press, Geologic map of the Huntsman Ranch quadrangle, Elko County, Nevada: Nevada Bureau of Mines and Geology Map, scale 1:24,000. 
Wannamaker, P.E., Doerner, W.M., and Rodriguez, B.D., 2002, Analysis of magnetotelluric profile data from the Ruby Mountains metamorphic core complex and southern Carlin trend region, Nevada: U.S. Geological Survey Open-File Report 02-214, 50 p.

Williams, J.M., and Rodriguez, B.D., 2003, Magnetotelluric data release for locating the Archean/Proterozoic suture zone, East-Central Tooele County, Utah: U.S. Geological Survey Open-File Report 03-495, 119 p. (http://pubs.usgs.gov/of/2003/ofr-03-495/)

Williams, J.M., and Rodriguez, B.D., 2004, Magnetotelluric survey to locate the Archean/Proterozoic suture zone in northeastern Nevada: U.S. Geological Survey Open-File Report 2004-1215, 212 p. (http://pubs.usgs.gov/of/2004/1215/)

Williams, J.M., and Rodriguez, B.D., 2005, Magnetotelluric survey to locate the Archean/Proterozoic suture zone in north-central Elko County, Nevada: U.S. Geological Survey Open-File Report 2005-1255, 183 p.

Yager, D.B., and Folger, H.W., 2005, A data viewer for stream-sediment and surface-water chemistry, geology, and geography of the Humboldt river basin, northern Nevada: U.S. Geological Survey Bulletin 2210-F, 9 p.

Yager, D.B., and Hofstra, A.H., 2004, A scaled relational database design for organizing and analyzing information-Application to geology and ore deposits of the Great Basin [abs.]: Geological Society of America, Abstracts with Programs, v. 36, no. 5, p. 150.

Yager, D.B., Wallace, A.R., and John, D.A., 2005, A relational database for Miocene to Holocene igneous rocks of the Great Basin, western USA-Implications for petrogenesis and mineral deposit research [abs.]: Geological Society of America, Abstracts with Programs, v. 37, no. 7, p. 419.

Yigit, O., Hofstra, A.H., Hitzman, M.W., and Nelson, E.P., 2006, Geology and geochemistry of jasperoids from the Gold Bar district, Nevada: Mineralium Deposita, v. 41, p. 527-547.

Zhang, X., Hofstra, A.H., Hu, R., Emsbo, P., Su,W., and Ridley, W. I., 2005, Geochemistry and $\delta 34 \mathrm{~S}$ of ores and ore stage iron sulfides in Carlin-type gold deposits, Dian-Qian-Gui area, P.R. China-Implications for ore genesis, in Mao, J., and Bierlein, F.P., eds., Mineral Deposit Research• Meeting the Global Challenge: Proceedings of the 8th Biennial SGA Meeting, Beijing, China, 18-21 August, 2005, p. 1107-1110. 


\section{Significant Metal Deposits of the Great Basin}
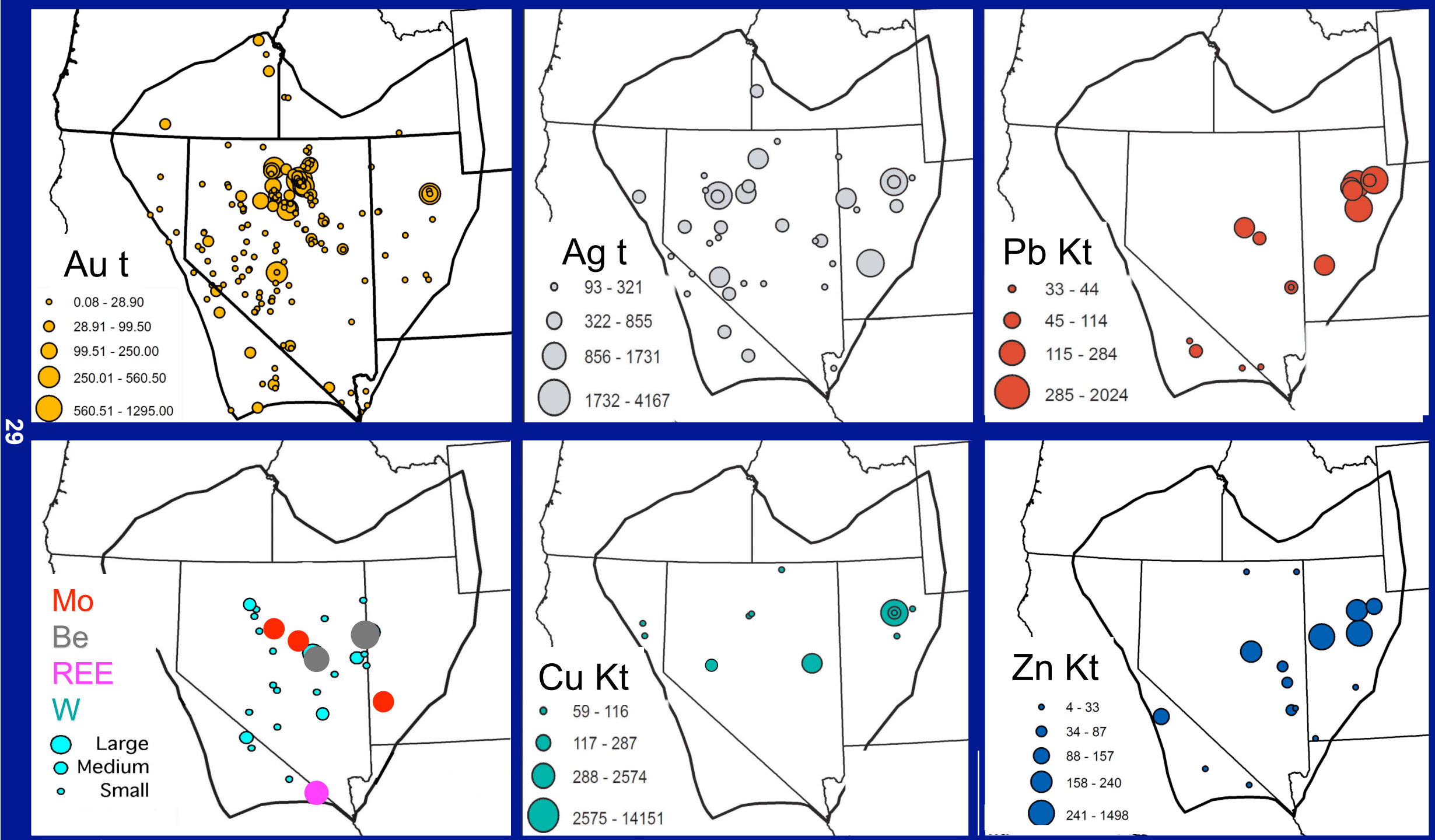

Fig. 1 


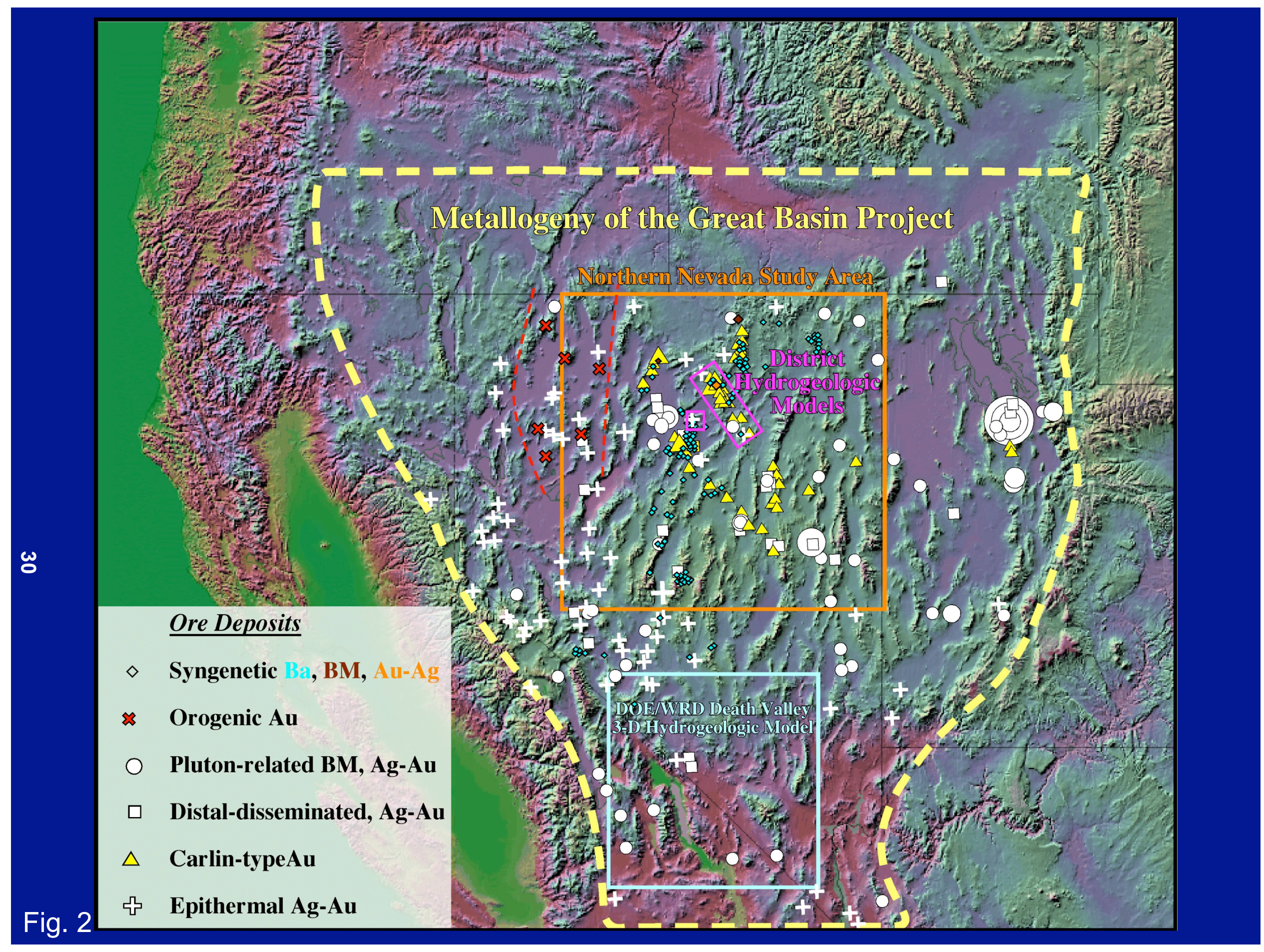




\section{Geophysical Terrains of the Great Basin}

\section{Magnetic Anomalies}

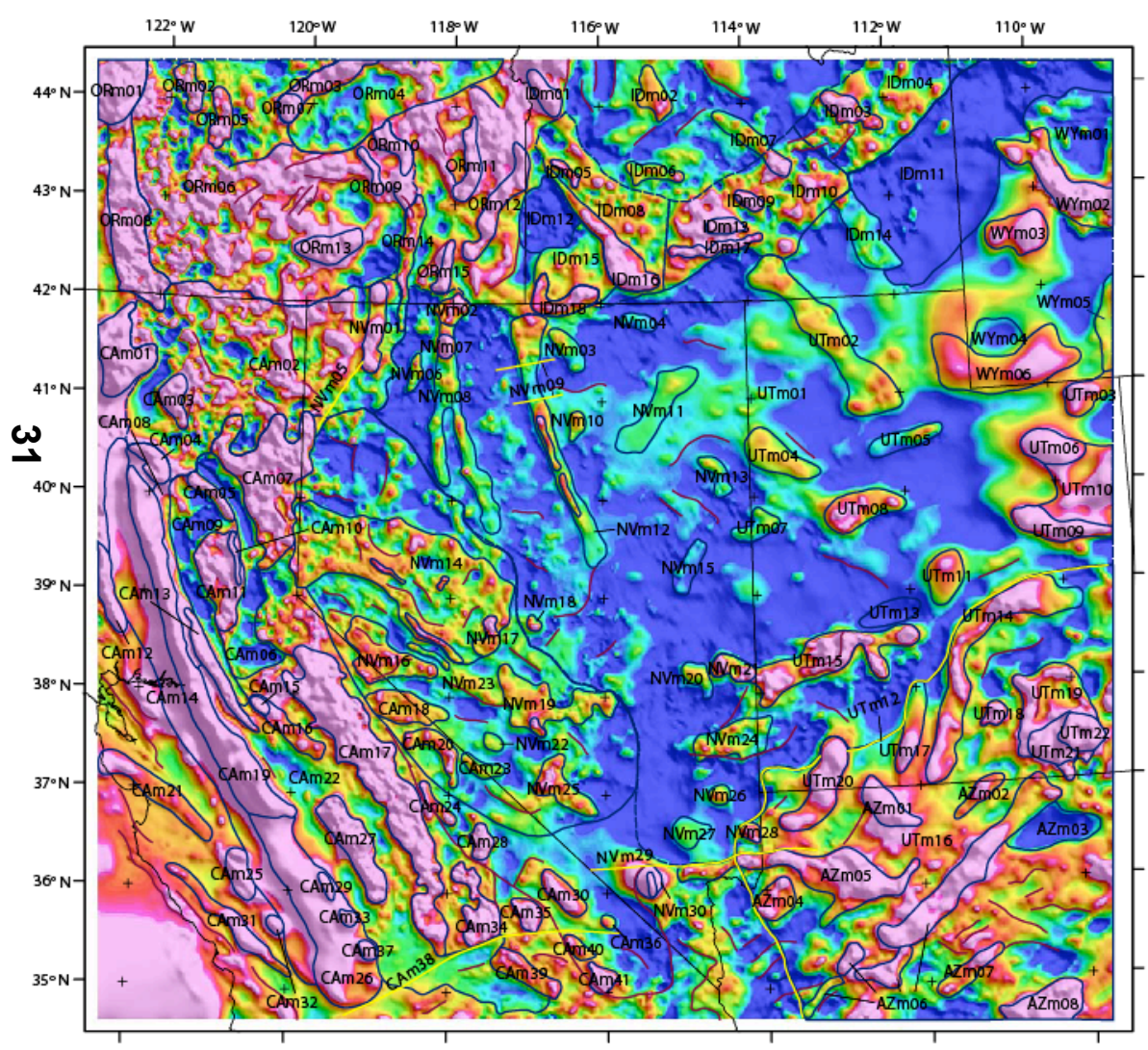

\section{Gravity Anomalies}

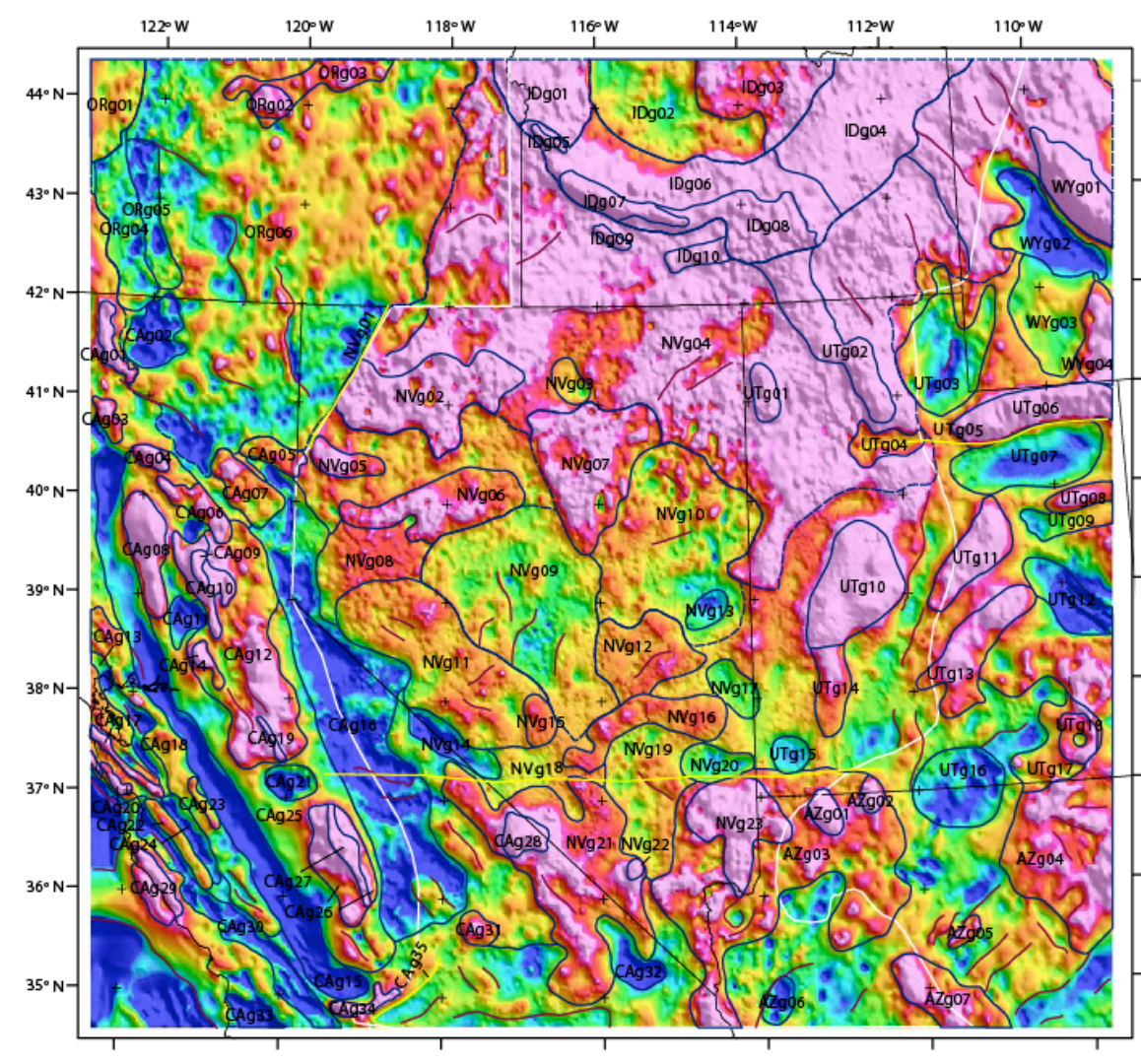

$250 \mathrm{~km}$

i

Fig. 3
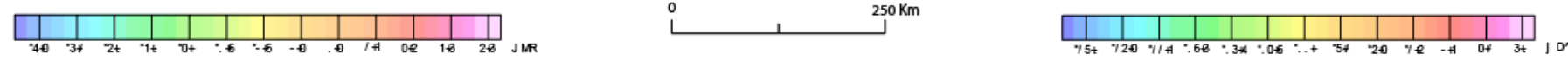


\section{Nevada State Digital Geologic Map}

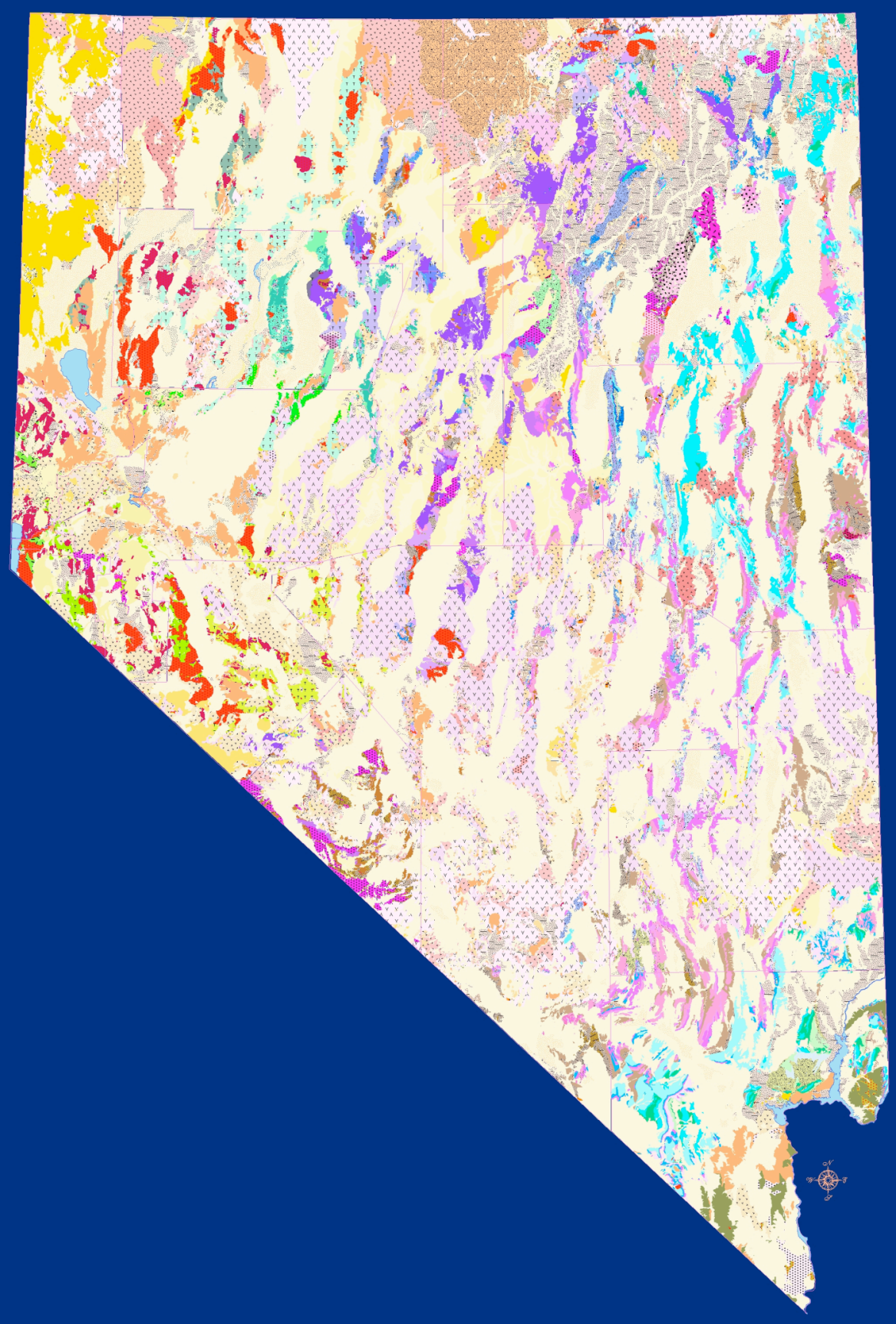

Fig. 4 


\section{Northern Nevada Study Area: Cross Sections}

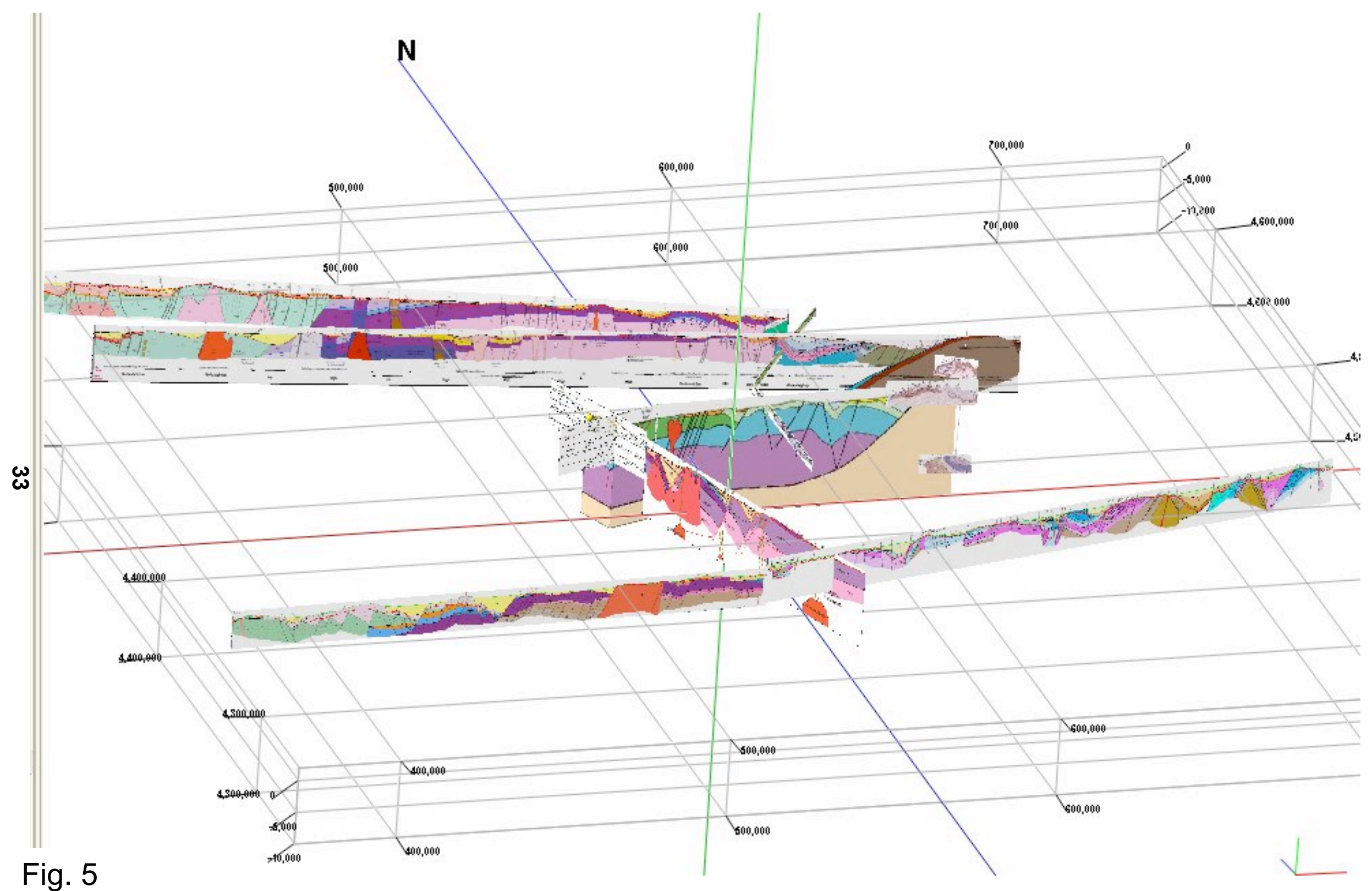


Simplified Hydrogeologic Model

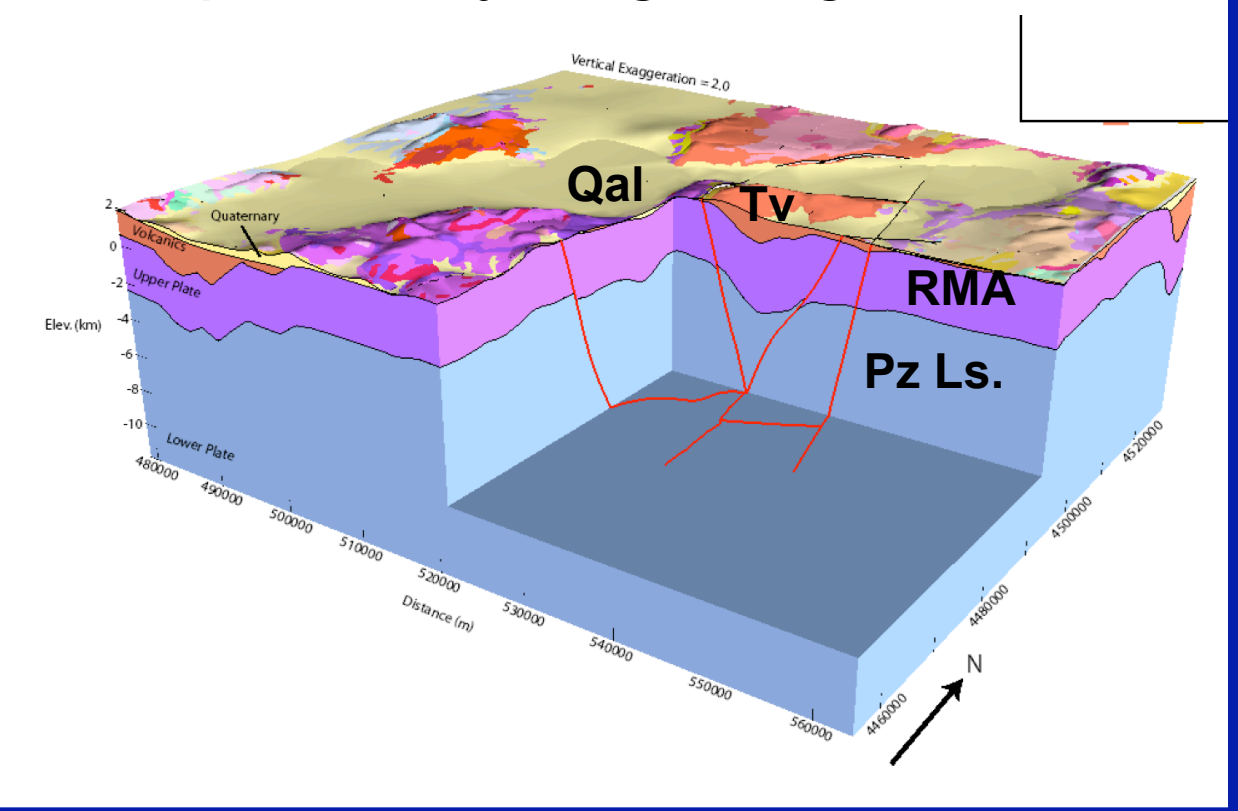

$\stackrel{\omega}{\perp}$

Future:

- 3-D flow models

- Flow models with plutons

- Chemical models of metal transport and deposition

\section{3-D Model \\ Beowawe \\ Geothermal Area}

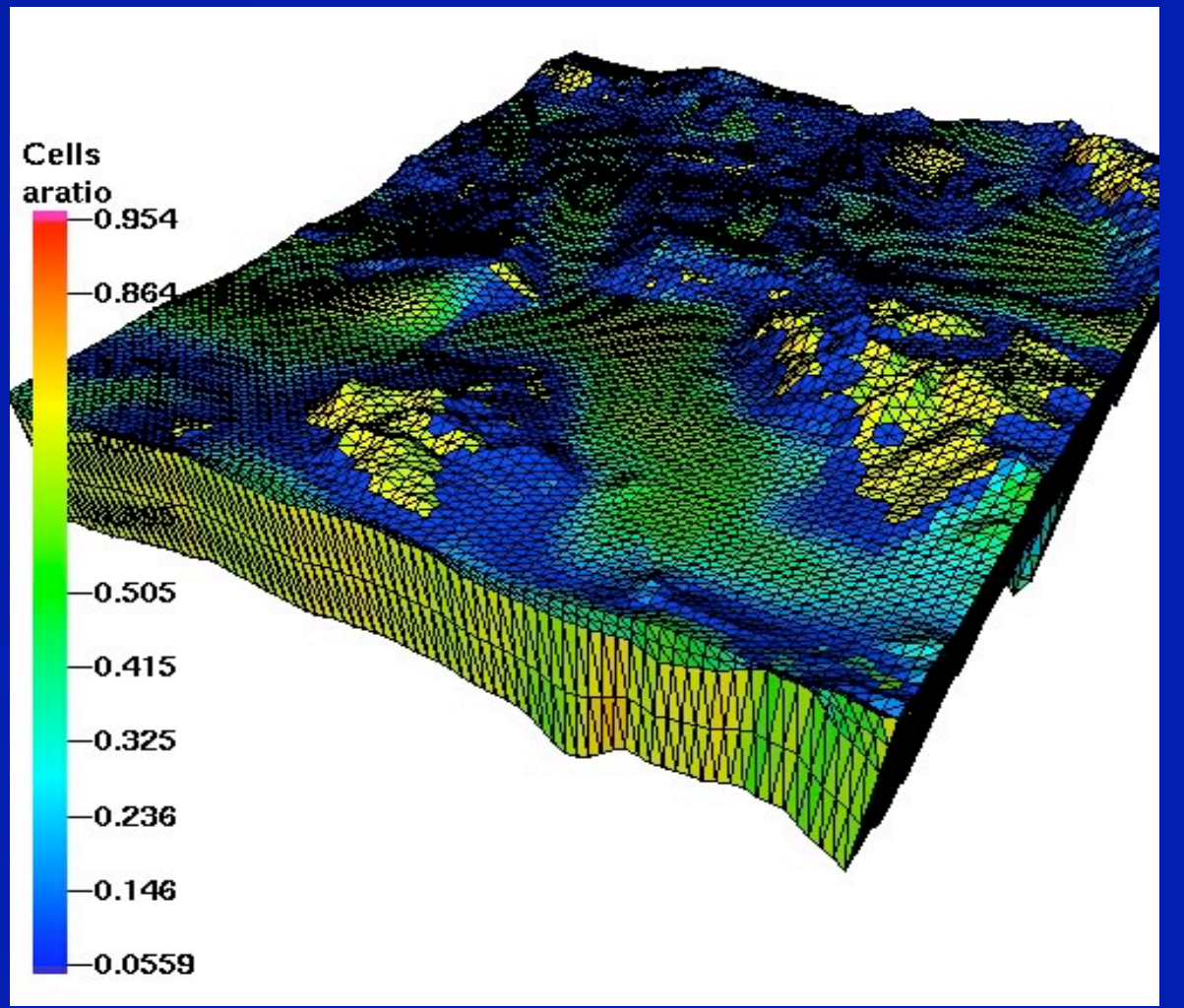

Fig. 6 


\section{"Present key to the past" approach to fluid flow modeling}

Constrained by geologic model, $T^{\circ} \mathrm{C}, \mathrm{AFT}$ data , 8180 of rocks and fluids

Beowawe Geothermal

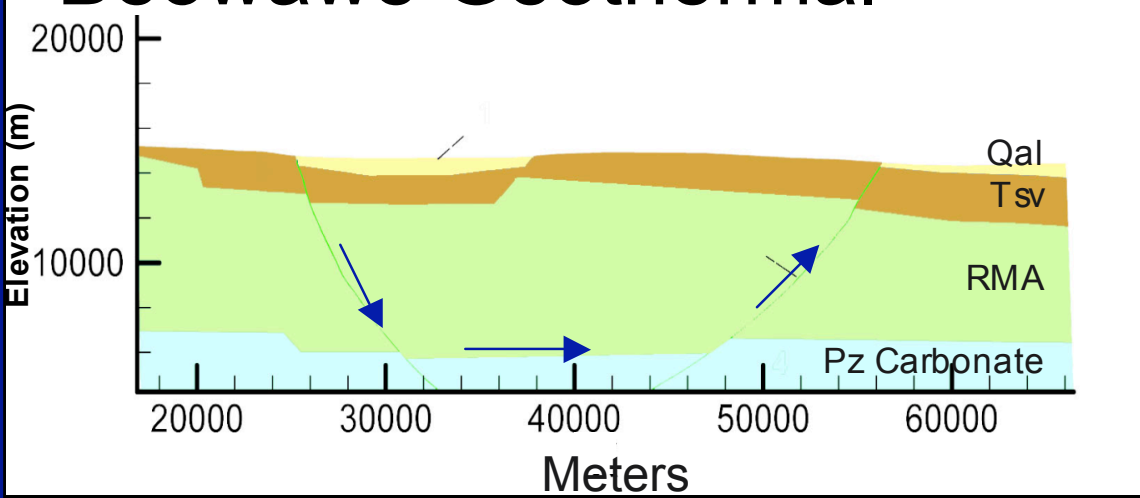

๗

\section{Eocene Carlin trend}

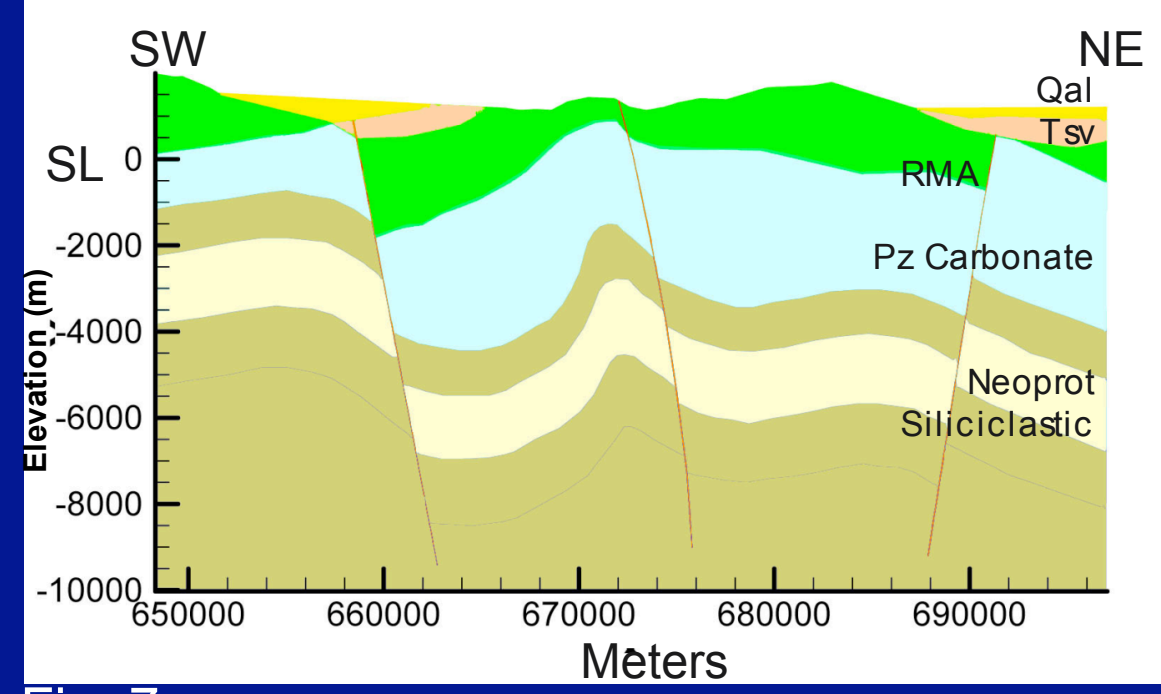

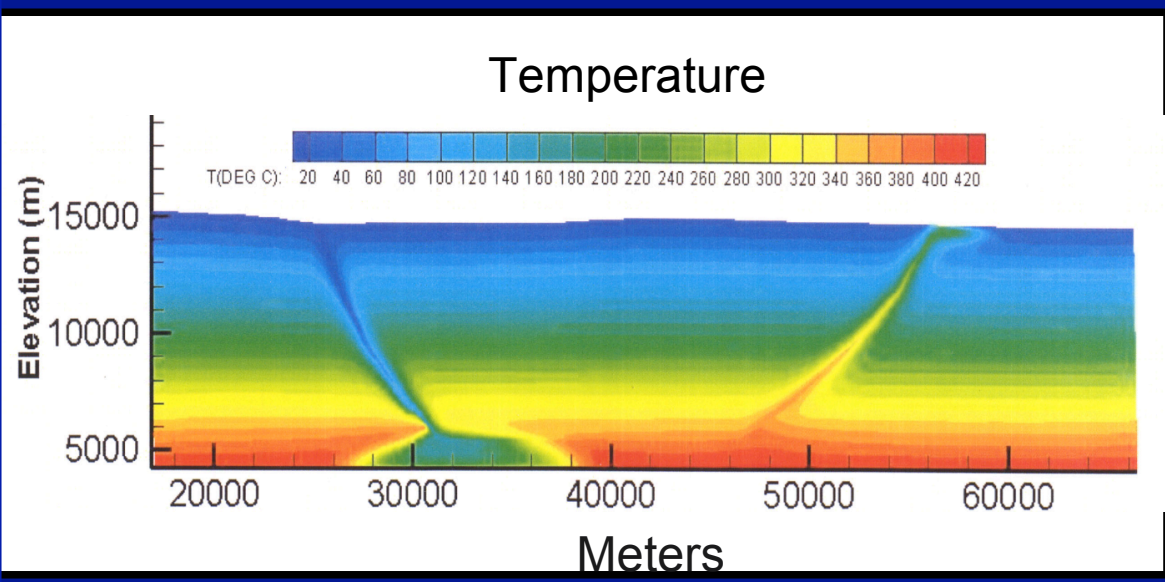

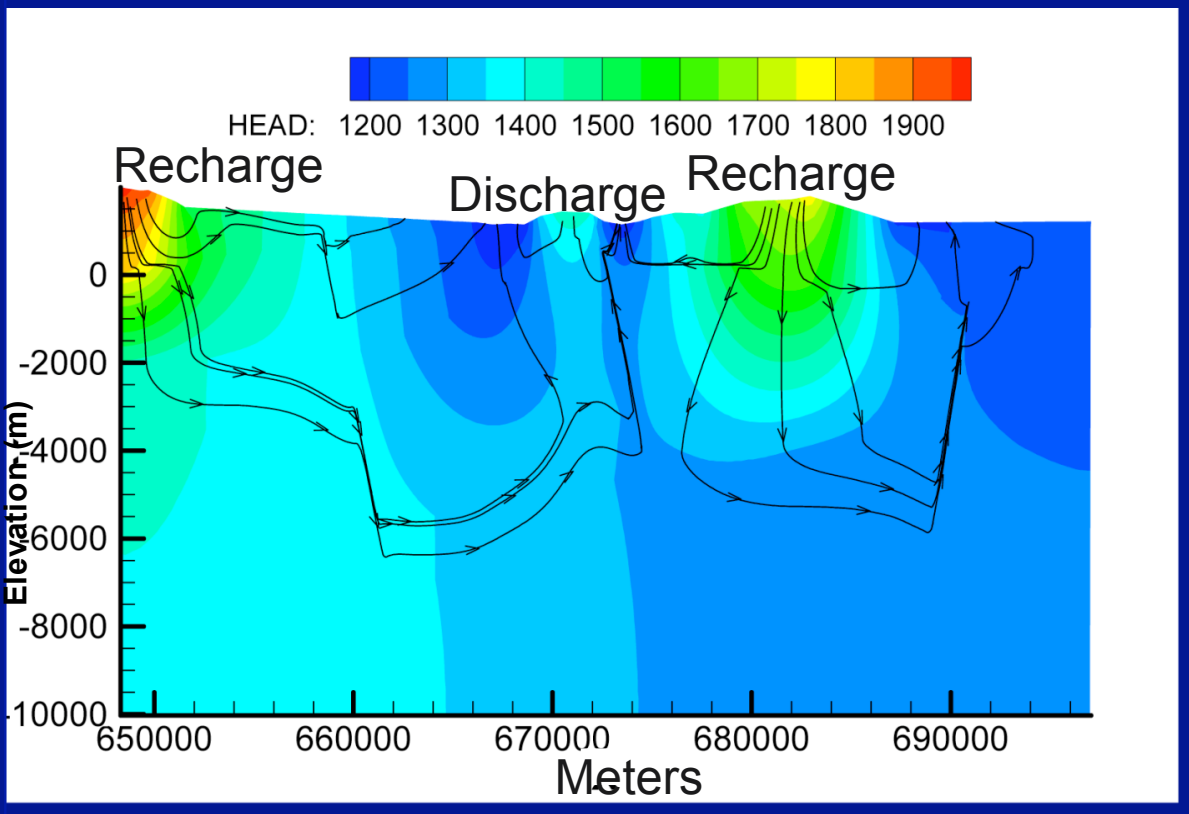

Fig. 7 


\section{Conceptual Database Mockup}

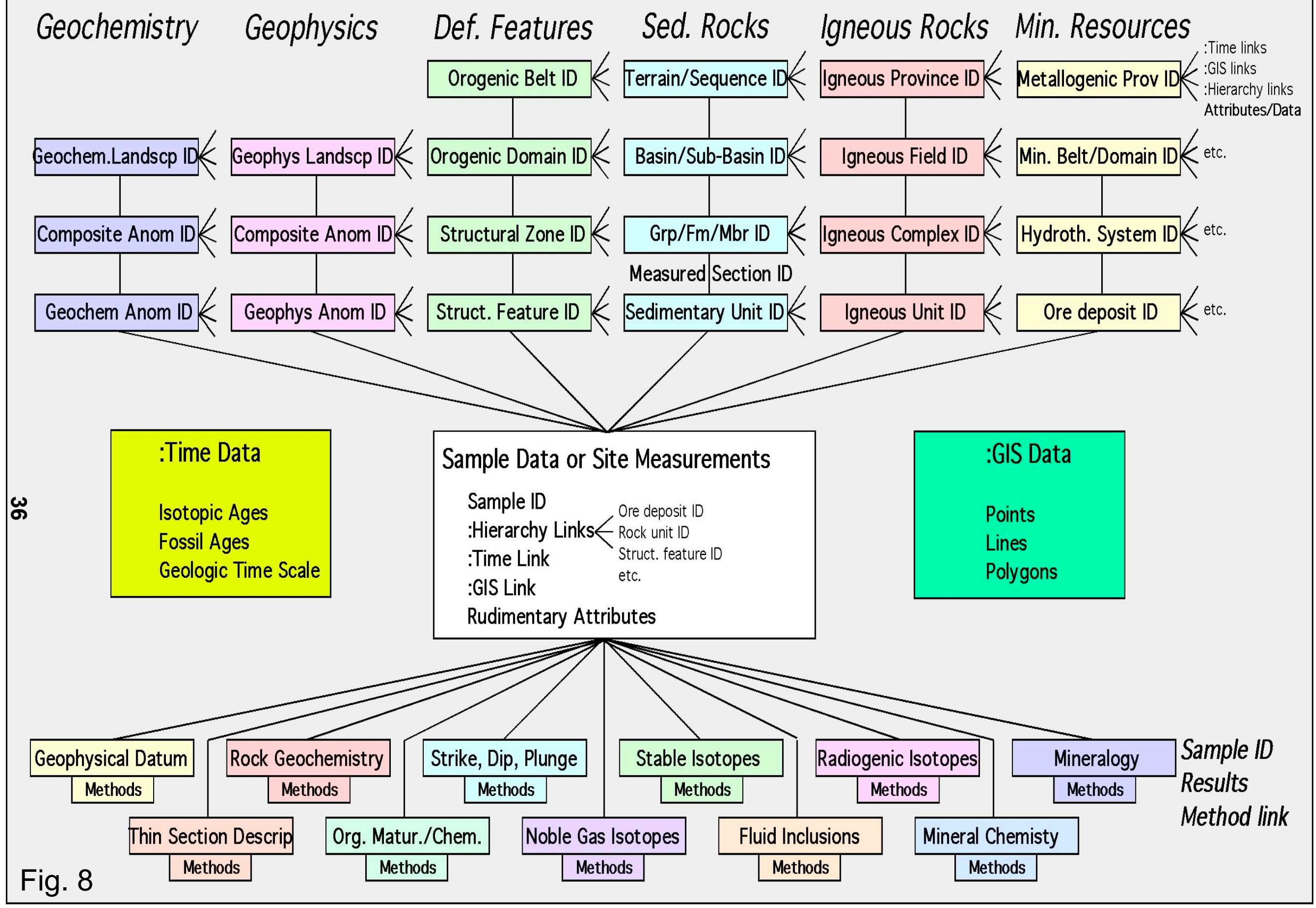

